\title{
Floristic notes on Palaearctic Laboulbeniales (Ascomycetes)
}

\author{
LARRY HULDÉN
}

\begin{abstract}
HULDÉN, L. 1985: Floristic notes on Palaearctic Laboulbeniales (Ascomycetes). Karstenia 25: 1-16.

Floristic notes are presented on 53 taxa of Laboulbeniales from various parts of the Palaearctic Region and one taxon from Taiwan. New species records are given for 33 countries or islands. Special attention is paid to the U.S.S.R., for which there are only scattered records in the literature. The northernmost records of Laboulbeniales are reported from Tit-Ary (Rickia hyperborea Balazuc) and Bulun (Laboulbenia vulgaris Peyritsch), by the Lena River, north of $70^{\circ} \mathrm{N}$ in Yakutia.

Laboulbenia egens Spegazzini, occurring on the carabidicolous genus Tachys (s.lat.), is recognized as a species separate from $L$. pedicellata Thaxter, occurring on the genera Bembidion (s.lat.) and Dyschirius. The variability of $L$. pedicellata is discussed.

Five new taxa are described: Laboulbenia broscosomae n.sp. on Broscosoma baldense Rosenh. from Italy, L. eubradycelli n.sp. on Bradycellus spp. from many European countries, L. kobilae n.sp. on Neotrechus suturalis ssp. suturalis Schr. from Yugoslavia, L. marvinii n.sp. on Bembidion dentellum (Thunb.) and B. starki Schaum from Austria, the Federal Republic of Germany and France, and L. luxurians subsp. immaculata n.subsp: on Bembidion semipunctatum (Donovan) from Austria and the Leningrad Region in the U.S.S.R.
\end{abstract}

Larry Huldén, Department of Entomology, Zoological Museum, P. Rautatiekatu 13, SF-00100 Helsinki, Finland.

\section{Introduction}

The fungus material in the present study is primarily based on the Palaearctic insect collection in the Zoological Museum of Helsinki (MZH). Additional material has been obtained from the insect collections of the Zoological Museum of Turku, Finland (cave insects from Sweden), the Zoological Museum of Bergen, Norway (Coleoptera from the Faeroes), the Institute of Zoology and Botany, Academy of Sciences of the Estonian S.S.R. in Tartu, U.S.S.R. (Coleoptera from Estonia), Mr. Björn Erling Waage and Dr. Dagfinn Refseth (Carabidae from Norway) and Prof. Alois Kofler (Coleoptera from Austria). Some specimens collected by myself in Estonia during the Second Estonian-Finnish Entomological Symposium in 1982 are also included. About 25000 specimens of selected material of Coleoptera (Carabidae, Gyrinidae, Staphylinidae), Diptera (Ephydridae, Nycteribidae) and Hymenoptera (Formicidae) were studied.

The preparation of the fungus material was done as described in Huldén (1983). The fungus material, including types, and the infected insects, except the borrowed specimens, are kept in a separate collection in $\mathrm{MZH}$.

Twenty taxa, including the new ones, are illustrated in this paper, most of the others in Huldén (1983). For Arthrorhynchus see Blackwell (1980a, 1980b), and for Rhachomyces see Lepesme (1942), Balazuc (1970) and Rossi (1978).

\section{Remarks on the distributional data}

As far as possible the locality information is given in accordance with modern atlases, because the labels on the old insect material may be rather cryptic unless supplemented with information from old diaries, etc. in the Zoological Museum of Helsinki. In the few cases in which the exact locality is not known, the smallest known modern geographical unit is given. In some exceptional cases, like 'Germania', the text is given as such, because the area extends over many countries nowadays. Old records from the present Israel with its immediate surroundings are given under Palestine.

The Laboulbeniales of the U.S.S.R. have previously been poorly studied. In this paper distributional data are given for 24 taxa from numerous localities. Due to the large area of the country, this means a significant extension of the known distribution of many species. As many of the locality names are poorly known and probably difficult to find, a map containing all the collecting sites in the U.S.S.R. (and one in Iran) is given in Fig. 1. Most of the localities on the labels could be interpreted with good accuracy except those in the Southern Urals in which G.A. Duske collected insects (shown as an open circle on the map).

The rest of the localities are presumably easy to identify. The Faeroes (belonging to Denmark), Azores and Madeira (Portugal) and the Canary Islands (Spain) are treated as separate units in the material lists. 


\section{Review of the species}

Floristic notes are presented for 54 taxa of the Laboulbeniales from 37 countries or islands. New species records are given for 33 countries and islands (marked with an asterisk *). The genera and species are in alphabetical order. The numbers in the countryspecies index refer to the species.

Albania *35

Algeria 35

Austria *4, 12, 14, *22, *23, 24, *26, 28, 30, 32, *34, 35, $* 36,39,41, * 46, * 49$.

Azores $* 35, * 52$.

Belgium *11.

Bulgaria 14, *31, 35 .

Canary Islands $* 9,14, * 35, * 36, * 38, * 53$.

Czechoslovakia *7, *9, 15, *21, 35, *37, *39.

Denmark *12,*36.

Egypt $* 9, * 27$.

Faeroes *14,*30,*35.

Federal Republic of Germany 14, 15, 21, *23, 27, 35 .

Finland $* 11, * 16$.

France $14, * 23,27,31,35,36,39,40,47$.

German Democratic Republic *5, *35, 39, *41, *49.

Greece *15, 27, *35, *36.

Hungary $* 41$.

Iran *36.

Ireland $* 4, * 14, * 27, * 35, * 36, * 39$.

Italy *6, *11, 35, *36, *43, 44, *45.

Lebanon $* 29$.

Madeira * $11, * 35$.

Morocco *35.

Netherlands $* 15,27,35$.

Norway *4, *5, *7, *11, *12,*14,*24,*25,*35,*37, 50 .

Palestine *9, *14, *35, *36.

Poland 12, 35 .

Romania 35, 39.

Spain $7, * 9,35,36$,

Sweden $2, * 3, * 4, * 5, * 7, * 8, * 10, * 12, * 15, * 27, * 31, * 35$, $* 37, * 39, * 41, * 49, * 54$.

Switzerland $* 3,4,14, * 15,30,35$.

Syria $* 35$.

Taiwan *1.

Turkey $* 27,35$.

United Kingdom *11, 12, 15, 24, 35, 39 .

U.S.S.R. 3, 4, 7, *10,*11, 12, *13, 14, 15, *16, *17, *18, $* 21, * 22, * 24,27,30,31, * 34,35,36,38,39,50$.

Yugoslavia *19, 33, 35, 41, 42, *51.

\section{Arthrorhynchus nycteribiae}

Laboulbenia nycteribiae Peyritsch 1871:451. Helminthophana nycteribiae (Peyritsch) Peyritsch 1873:250. - Arthrorhynchus nycteribiae (Peyritsch) Thaxter 1901:408.

Material examined

*Taiwan. Tainan. On Penicillidia jenynsii (Westw.) (Diptera, Nycteribiidae). No data on the host species of the bat fly.

\section{General distribution}

Compiled from Ryberg (1947), Balazuc (1971) and Blackwell (1980a): Austria, Burma, Czechoslovakia, Denmark, France, Hungary, Italy, Kenya, Netherlands, Poland ('East Prussia'), Romania, Spain, Sri Lanka, Sweden, Yugoslavia and Zambia.

Host

Batflies of the genera Eucampsipoda, Nycteribia, Penicillidia and Phthiridium (Diptera, Nycteribiidae).

\section{Asaphomyces tubanticus}

Barbariella tubantica Middelhoek \& Boelens in Middelhoek 1949:260. Asaphomyces tubanticus
(Middelhoek \& Boelens) Scheloske 1969:92.

Material examined

Sweden. Skåne: Tykarpsgrottan, on Catops fuliginosus Erichson. Balsbergsgrottan, on Catops fuliginosus and $C$. nigricans (Spence). The hosts were found in caves in both localities.

\section{General distribution}

Czechoslovakia, Federal Republic of Germany, Finland, France, Italy, Netherlands, Poland, Sweden and U.S.S.R. (Huldén 1983).

Host

Catops spp., Catopoides spp. and Sciodrepoides spp. (Coleoptera, Carabidae).

\section{Cantharomyces orientalis}

- Figs. 4a-d Cantharomyces orientalis Spegazzini 1915b:43.

Variable in size, $130-240 \mu \mathrm{m}$ in length. Larger specimens have the basal cells of the perithecium more elongated than small specimens. The compound antheridium variable, situated on the second appendage cell (Figs. $4 \mathrm{~b}$ and d). The differences in size and habitus do not seem to be correlated with the host species.

Material examined

*Sweden. Uppland: Stockholm, on Carpelimus corticinus (Gravenhorst). *Switzerland. Ticino: Chiasso, on C. opacus Baudi. U.S.S.R. *Yakut A.S.S.R.: Nikolsk and Ytyk-Haja, on C.corticinus.

General distribution

Algeria, Federal Republic of Germany, Finland, Italy, Netherlands, Poland and U.S.S.R. (Huldén 1983).

Host

Carpelimus spp. (Coleoptera, Staphylinidae).

\section{Laboulbenia argutoris}

\section{Laboulbenia argutoris Cépède \& Picard 1909:260.}

Material examined

*Austria. Hohe Tauern (Pterostichus diligens (Sturm)).

*Ireland. Kerry: Killarney (P. diligens, P. strenuus (Panzer)).

*Norway. Hordaland: Linga (P. strenuus). *Sweden. Skåne:

Ringsjön ( $P$. diligens). - Uppland ( $P$. strenuus). Switzerland.

Graubunden: Engadin ( $P$. diligens). U.S.S.R. *Estonian S.S.R.: Harju r., Nõmmeveski (P. strenuus).

General distribution

Federal Republic of Germany, Finland, France, Hungary, Italy, Poland, Romania, Switzerland and U.S.S.R. (Huldén 1983).

Host

Pterostichus spp. (Coleoptera, Carabidae).

\section{Laboulbenia bradycelli}

Laboulbenia bradycelli Balazuc 1974, in Balazuc 1973-74, vol. 43:15.

Material examined

*German Democratic Republic. Eberswalde: Chorin (Trichocellus placidus (Gyllenhal)). *Norway. Hordaland: Skogsöy (Bradycellus ruficollis (Stephens)). *Sweden. Uppland: Stockholm (Trichocellus placidus).

General distribution

Finland, France, Poland and U.S.S.R. (Huldén 1983).

Host

Trichocellus placidus and Bradycellus spp. (Coleoptera, Carabidae). 


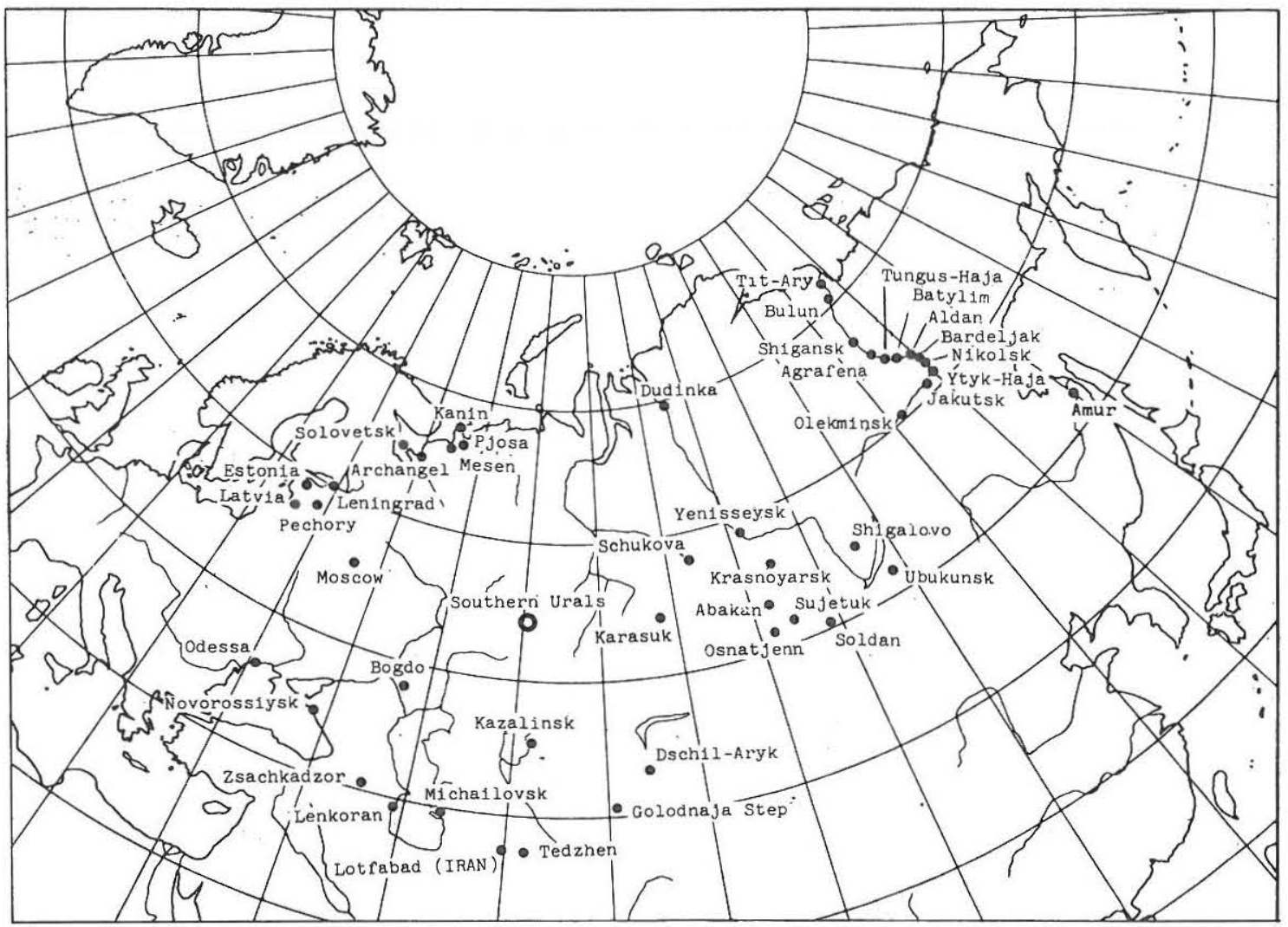

Fig. 1. Localities of Laboulbeniales records in the U.S.S.R.

\section{Laboulbenia broscosomae Huldén n.sp.}

- Fig. 16 Crassulus. Matrix: Broscosoma baldense Rosenhauer. Receptacle. Pale yellowish, slightly darkened along the margin of the appendical side. Cells I-II forming a stalk about $110 \mu \mathrm{m}$ in length, $25-35 \mu \mathrm{m}$ in width. Cell I distinctly shorter than cell II. Cells III-IV about $60 \mu \mathrm{m}$ in length, cell III longer than cell IV. Cell V small, oblique, not connected with cell III. Cell IV nearly isodiametric, about $25 \mu \mathrm{m}$ in width.

Appendages. Insertion cell externally broadly black, situated slightly below middle of the perithecium. Outer appendage consisting of a simple row of at least seven cells, which are equal in size, $25 \mu \mathrm{m}$ in length and $15 \mu \mathrm{m}$ in width. Inner appendage consisting of two simple rows of cells similar to that of the outer appendage, except for the basal cell which is about $13 \mu \mathrm{m}$ in width. One antheridium visible on the second cell of the inner appendage. The appendages $125-150 \mu \mathrm{m}$ in length.

Perithecium. Brown, paler near the sutures of the cells, blackish around the tip. Habitus robust, rounded and stout, tip nearly straight, size about 60 x $120 \mu \mathrm{m}$. Spores not observed.

Total length from base of foot to tip of perithecium about $250 \mu \mathrm{m}$.

Host. Broscosoma baldense Rosenh. (Coleoptera,
Carabidae).

Holotype. Slide L. Huldén 26, in MZH. Collecting data of the host: Italy. Mte. Baldo.

Spegazzini (1914) reported another species, L. rigida Thaxter, from the same host and locality. His microphotograph (Fig. 54) shows that his material represents $L$. broscosomae. $L$. broscosomae differs from $L$. rigida in its more rounded and clumsy habitus and different host genus (L. rigida was described from Pterostichus).

Material examined. See the type.

\section{Laboulbenia clivinalis}

Laboulbenia clivinalis Thaxter 1899:165.

Material examined

*Czechoslovakia. Paskau (near Ostrava), on Clivina collaris (Herbst). *Norway. Hordaland: Linga (Clivina fossor (Linnaeus)). Spain. Guipuzcoa: Irun (C. fossor). "Sweden. Öland: Vickleby ( $C$. fossor): U.S.S.R. *Archangel Region: Solovetsk Islands (C. fossor). - "Caucasus (C. fossor).

General distribution

Algeria, Federal Republic of Germany, Finland, France, Hungary, Italy, Philippines, Poland, Spain, United Kingdom and U.S.S.R. (Huldén 1983).

Host

Clivina spp. (Coleoptera, Carabidae).

\section{Laboulbenia curtipes}

Laboulbenia curtipes Thaxter 1892:40.

Material examined

*Sweden. Skåne: Bökeberg. On Bembidion obliquum Sturm. 
General distribution

Finland, U.S.A. and U.S.S.R. (Huldén 1983).

Host.

Bembidion: subgen. Notaphus and B. dentellum (Thunberg) (Coleoptera, Carabidae).

\section{Laboulbenia egens} - Figs. 22a-b

Laboulbenia paupercula Spegazzini 1915b:59, auct. non Thaxter 1891:269. - Laboulbenia egens Spegazzini 1918:323.

This species has been confused with $L$. pedicellata. It grows on Tachys species (Coleoptera, Carabidae), while $L$. pedicellata occurs mainly on the genera Dyschirius and Bembidion (s.lat.). L. egens is distinctly separable from $L$. pedicellata by its smaller lip cells (more pointed perithecium), more or less distinct humps on outer side on perithecium, usually vertical and slightly shorter septum IV-V (in L. pedicellata it is normally slightly oblique, but this character is not constant) and strongly protruding first cell of outer appendage (see Fig. 22b). The last-mentioned character is typical of $L$. picardii Maire and $L$. tachyis Thaxter, also occurring on Tachys spp, but these species, do not have septum IV-V connected with septum III-IV.

L. tachyis has been reported from Japan on Tachys laetificus Bates (Sugiyama 1973), from Hungary on Tachyta nana (Gyllenhal) (Banhegyi 1949) and from Taiwan on Tachys klugii Nietner (Sugiyama 1978). The illustration in Sugiyama (1973), however, represents $L$. egens. The two latter references lack illustrations, but the reports probably also represent L. egens. Balazuc's (1973-74, 1978, 1982) reports of L. pedicellata from France, Madagascar and Guadeloupe on Tachys (s.lat.) also seem to represent L. egens, cf. illustration in Balazuc (1982).

Material examined.

* Canary Islands. (Spain), Gran Canaria: Arucas (Tachys haemorrhoidalis (Ponza)). - Tenerife (T. haemorrhoidalis).

*Czechoslovakia. Paskau (T. quadrisignatus (Duftschmid)).

*Egypt. Cairo. (T. lucasi Duval, T. fumigatus ssp. socius Schaum). - Luxor (T. lucasi). *Palestine. Jericho(T. lucasi).

*Spain. Cordoba (T. lucasi).

\section{General distribution}

Compiled from the literature and my own records (see comments above): Canary Islands, Czechoslovakia, Egypt, France, Guadeloupe, Hungary, Japan, Madagascar, Palestine, Spain and Taiwan.

Host

Tachys (s.lat.) spp. (Coleoptera, Carabidae).

10. Laboulbenia elaphri

Laboulbenia elaphri Spegazzini 1915a:464.

Material examined

* Sweden. Uppland: Stockholm, on Elaphrus cupreus Duftschmid. *U.S.S.R. Estonian S.S.R.: Seadjärv, on E. cupreus.

General distribution

Belgium, Denmark, Federal Republic of Germany, Finland, France, Hungary and Poland (Huldén 1983).

Host

Elaphrus cupreus and E. riparius (Coleoptera, Carabidae).
11. Laboulbenia eubradycelli Huldén n.sp.

- Figs. 2 (map), 12a-c

Ut Laboulbenia bradycelli sed sporis majoribus. Matrix: Bradycellus spp.

Receptacle. Pale yellowish, cell I usually brownish in distal part, cells III-IV to variable degree brownish, darkening upwards. Cells I-II forming a rather elongated stalk, $120-200 \mu \mathrm{m}$ in length, the width increasing from about $20 \mu \mathrm{m}$ at the base to $25-50 \mu \mathrm{m}$ in the upper part. Cell I usually distinctly shorter than cell II. Cells III-IV $55-70 \mu \mathrm{m}$ in length, cell III being slightly longer than cell IV. Cell V rather small, not connected with cell III. Cell VI almost isodiametric or slightly elongated, about $20-35 \mu \mathrm{m}$ in width.

Appendages. Insertion cell externally sharply or diffusely blackish brown, situated below middle of perithecium. Outer appendage consisting of a single row of $5-10$ cells about equal in length distally slightly narrowing. Inner appendage consisting of a small brush of about $5-10$ branchlets, each terminating in an antheridium. Width of basal cell os inner appendage $1 / 2$ to $3 / 4$ of that of basal cell of outer appendage. Length of outer appendage about $100-150 \mu \mathrm{m}$, inner appendage shorter and not usually reaching tip of perithecium.

Perithecium. Brown, the sutures of the cells darker. Black spots on lip cells. Perithecium straight but tip slightly oblique. Size $40-70 \times 85-125 \mu \mathrm{m}$. Spores about 3 X $45 \mu \mathrm{m}$.

Total length from base of foot to tip of perithecium $230-370 \mu \mathrm{m}$.

Host. Bradycellus harpalinus (Audinet-Serville), $B$. caucasicus Chaudoir, B. ruficollis (Stephens) (Coleoptera, Carabidae). Probably also many other Bradycellus species. The parasite occurs on various parts of the host.

Holotype. Slide L. Huldén 1, in MZH. On Bradycellus caucasicus. Collecting data of the host: Finland. Ab: Lohja, 7.V.1893 Luther.

In Huldén (1983) this species occurring on Bradycellus spp. was wrongly interpreted as Laboulbenia polyphaga Thaxter. Laboulbenia eubradycelli differs from that species in its larger size, larger lip cells, angular habitus of the perithecium and more strongly pigmented thallus. It is closely related to $L$. bradycelli, described by Balazuc (1974, in 1973-74). L. bradycelli seems to be much more common on Trichocellus placidus Gyllenhal) than on Bradycellus spp. It is possible that some material of $L$. bradycelli studied by Balazuc in fact belongs to the new species. L. bradycelli is differentiated by its smaller size $(130-200 \mu \mathrm{m}$ against $230-370 \mu \mathrm{m}$ for L. eubradycelli), cells I and II about equal in length, the somewhat greenish tinge of the dark pigmentation, simpler inner appendage, longer cells of outer appendage, basal cell of outer appendage more than twice the size of basal cell of inner appendage, flatter cell VI, more oblique tip of perithecium and slightly smaller spores (about $38 \mu \mathrm{m}$ against about $45 \mu \mathrm{m}$ for L. eubradycelli).

The new species varies somewhat in the shape of the perithecium, which usually has an angular 


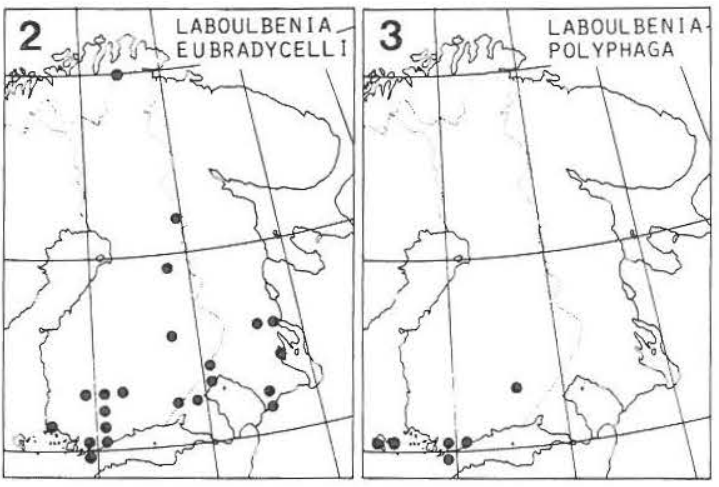

Figs. 2-3. - Distribution of 2) Laboulbenia eubradycelli and 3) L. polyphaga in Eastern Fennoscandia.

appearance, but may also be more rounded (filled with spores) or rather narrow. The spores are usually about $45 \mu \mathrm{m}$ in length, but in one case they were $42 \mu \mathrm{m}$ and in another about $48 \mu \mathrm{m}$. These probably represent different strains within the species.

The distribution of Laboulbenia eubradycelli and L. polyphaga in Eastern Fennoscandia are given in Figs. 2 and 3 because of the previous confusions in Huldén (1983).

Material examined

*Belgium. Brabant: Tervuren (Bradycellus harpalinus). ${ }^{2}$ Finland. Ab: Uusikaupunki (B. ruficollis, B. caucasicus). Lohja (B. caucasicus). Vihti (B. caucasicus). Turku (B. caucasicus). N: Hangö, Tvärminne (B. ruficollis, $B$. caucasicus). Helsinki (B. caucasicus). Espoo. (B. caucasicus). Tuusula (B. caucasicus) Sjundeå. (B. caucasicus). - Ta: Hartola ( $B$. caucasicus). Ylöjärvi (B. caucasicus). Pälkäne (B. caucasicus). Hattula (B. caucasicus). - Sa: Joutseno (B. caucasicus). - Sb. Vehmersalmi (B. caucasicus). - Kb: Kitee (B. caucasicus). - Ok: Ristijärvi (B. caucasicus). - Ks: Kuusamo (B. caucasicus). - Li: Utsjoki (B. caucasicus). *Italy. 'Parco Abruzzo' (B. caucasicus). *Madeira. (Portugal). On B. harpalinus. "Norway. Hordaland: Skogsöy (B.harpalinus). Sör-Tröndelag: Agdenes ( $B$. caucasicus) *United Kingdom. Scotland: Moray, Forres (B. caucasicus). *U.S.S.R. Leningrad Region: Kamennogorsk (Antrea). Segeza. Uslanka. - Karelian A.S.S.R.: Sortavala, Pirknitsa, Ahvenjärvi. Kendjärvi. Semsjärvi. All records on $B$. caucasicus.

\section{Laboulbenia fasciculata}

Laboulbenia fasciculata Peyritsch 1873:248.

In Finland this species occurs only in the south (Huldén 1983). It is interesting to note that on the Norwegian coast it reaches as far north as the Troms region, thus very exactly following the distribution of Patrobus atrorufus (Ström).

\section{Material examined}

Austria. Kärnten: Koralpe (Patrobus styriacus Chaudoir). Tirol ( $P$. septentrionis Dejean). - Steiermark: Turnau ( $P$. styriacus). *Denmark. Själland: Dyrehaven (P.atrorufus (Ström)). *Norway. Hordaland: Asköy, Gjerstad. Hjeltnes. Ullensvang. Nordheimsund. Linga ( $P$. atrorufus). Ystanes (Synuchus vivalis (Illiger)). - Möre og Romsdal: Molde ( $P$. atrorufus). Sjöholt ( $P$. atrorufus, $P$. assimilis). - SörTröndelag: Trondheim. Melhus. Rognes. (P. atrorufus). Troms: Finsnes (P. septentrionis). Poland: Katowice: Cieszyn
(P. atrorufus). *Sweden. Uppland: Lidingö ( $P$. atrorufus). - Gotland: Klinte. (P. atrorufus). United Kingdom. Scotland. Moray, Forres (P. assimilis Chaudoir). U.S.S.R. Estonian S.S.R.: Paldiski, Väike-Pakri s. (P. atrorufus). - *Pskov Region: Pechory (P. atrorufus).

\section{General distribution}

Holarctic, in Europe known from Austria, Federal Republic of Germany, Finland, France, Greece, Hungary, Italy, Poland, Romania, Spain, Switzerland, United Kingdom, U.S.S.R. (Leningrad Region, Karelian A.S.S.R., Estonian S.S.R., Latvian S.S.R.) (Balazuc et al. 1983, Huldén 1983).

Host

Patrobus atrorufus is presumably the main host, but $L$. fasciculata also occurs on many other species of Patrobus and related genera (Coleoptera, Carabidae).

\section{Laboulbenia fennica}

Laboulbenia fennica Huldén 1983:54.

Material examined

*U.S.S.R. Estonian S.S.R.: Vastse-Kuuste, Lootvina (Gyrinus marinus Gyllenhal).

General distribution

Previously reported only from Finland (Huldén 1983).

Host.

Gyrinus spp. G. aeratus Stephens being the main host in Finland (Coleoptera, Gyrinidae).

\section{Laboulbenia flagellata}

Laboulbenia flagellata Peyritsch 1873:247.

Material examined

Austria. Tirol. (Agonum moestum (Duftschmid)). Burgenland: Neusiedler See (A. thoreyi Dejean). Bulgaria. Rila Mountais. (Agonum antennarium (Duftschmid. Canary Islands (Spain). Gomera (A. marginatum (Linnaeus)). *Faeroes (Denmark). Vagar: Sörvagur (Patrobus septentrionis Dejean). - Suduroy: Ven ( $P$. septentrionis). Federal Republic of Germany. Hamburg (A. micans (Nicolai)). France. Allier: Vichy (A. moestum (Duftschmid)). "Ireland. Kerry: Killarney (A. muelleri (Herbst)). *Norway. Troms: Finsnes (Patrobus septentrionis). - Sör-Tröndelag: Melhus (A. micans). *Palestine. Kafr Kanna (A. nigrum Dejean). Switzerland. Solothurn: Dornach (A.viduum (Panzer), A. muelleri). U.S.S.R. Moscow (A. thoreyi). - Krasnoyarsk (A. bicolor Dejean). - Novorossiysk (A. nigrum). - Tuva A.S.S.R.: Soldan (A. thoreyi).

General distribution

Nearly cosmopolitan (Huldén 1983).

Host.

Mainly Agonum spp. (Coleoptera, Carabidae).

\section{Laboulbenia giardii}

Laboulbenia giardii Cépède \& Picard 1909:258.

Material examined

Federal Republic of Germany. Niedersachsen: Helmstedt. (Dicheirotrichus gustavi Crotch). ${ }^{*}$ Greece. Attika: Elevsis (D. obsoletus (Dejean)). *Netherlands. Texel: De Koog (D. gustavi). *Sweden. Bohuslän: Koster (D. gustavi). *Switzerland. Valais: Saxon (D. gustavi). United Kingdom. Scotland: Moray, Forres (D. gustavi). U.S.S.R. *Novosibirsk Region: Karasuk steppe (D. obsoletus). - *Archangel Region: Solovetsk Islands (D. gustavi). - Ural Mts., no locality (Dicheirotrichus sp.).

General distribution

Finland, France, 'Germania', Hungary, Italy, United Kingdom and U.S.S.R. (Karelian A.S.S.R., Tomsk Region), (Huldén 1983). 
Host

Dicheirotrichus spp. (Coleoptera, Carabidae).

16. Laboulbenia gyrinicola

Laboulbenia gyrinicola Spegazzini 1914:34.

Material examined

*Finland. Al: Jomala (Gyrinus natator (Linnaeus)). *U.S.S.R. Estonian S.S.R.: Tartu r., Vahi (G. substriatus Stephens). - Põlva r., Taevaskoja (G. natator, G. marinus Gyllenhal).

\section{General distribution}

Algeria, Belgium, Czechoslovakia, France, Hungary, Italy, Poland, Romania, Sweden, Switzerland, Yugoslavia (Huldén 1983). Records from the United Kingdom and Spain possibly concern L. fennica.

\section{Host}

Gyrinus spp. and Aulonogyrus spp. (Coleoptera, Gyrinidae).

\section{Laboulbenia hastiana}

Laboulbenia hastiana Huldén 1983: 55.

This species is closely related to $L$. vulgaris and can be regarded as one extreme in the vulgaris comples. I still prefer to treat it as a separate species, as it seems to be confined to Bembidion hasti.

Material examined

*U.S.S.R. Archangel Region: Kanin (Bembidion hasti Sahlberg).

General distribution

Finland (Huldén 1983)

Host

Bembidion hasti (Coleoptera, Carabidae).

18. Laboulbenia ishikawai

Laboulbenia ishikawai Sugiyama 1973:52. - Fig. 11

Material examined

*U.S.S.R. Khabarovsk Region, Amur River (Diplous depressus (Gebler)).

General distribution

Japan (Sugiyama 1973).

\section{Host}

Diplous spp. (Coleoptera, Carabidae).

19. Laboulbenia kobilae Huldén n.sp.

Matrix: Figs. $15 \mathrm{a}-\mathrm{b}$ Schaufuss.

Receptacle. Yellowish, with strong blackish broen pigmentaiton from the upper part of cell I upwards. Cells I-II forming a stalk $180-200 \mu \mathrm{m}$ in length, evenly broadening from $20 \mu \mathrm{m}$ to $40 \mu \mathrm{m}$ in the upper part. Cells III and IV equal in size, $20 \times 60 \mu \mathrm{m}$. Cell V small, triangular, about $15 \mu \mathrm{m}$ in height. Cell VI triangular-isodiametric, $25-30 \mu \mathrm{m}$ in width.

Appendages. Insertion cell externally black, appendage cells yellow. Basal cell of outer appendage rather robust, $25-30 \mu \mathrm{m}$ in length, width at base about $18 \mu \mathrm{m}$ and in upper part about $10 \mu \mathrm{m}$, size of the second cell about $10 \times 15 \mu \mathrm{m}$, third cell broken near the base. Basal cell of inner appendage almost isodiametric, $10 \mu \mathrm{m}$ in width. Inner appendage branching dichotomously twice, just reaching tip of perithecium.
Perithecium. Blackish brown, black spot on inner side near the yellow tip. Size $40-45 \times 135-140 \mu \mathrm{m}$. Only upper fourth of perithecium free, abruptly narrowing towards the slightly outwards bent tip. Spores about $5 \times 55 \mu \mathrm{m}$ in size.

Total length from base of foot to tip of perithecium $330-350 \mu \mathrm{m}$.

Host. Neotrechus suturalis ssp. suturalis Schaufuss (Coleoptera, Carabidae). The parasite was found on the pronotum of the host.

Holotype. Slide L. Huldén 27, in MZH. Collecting data of the host: Yugoslavia. Bosnia-Hercegovina: Kobila Glava.

Relationship with other species unclear. L. shanorii Banhegyi, described from the same host, is quite different (see Fig. 14). The exact structure of the appendages is not certain; the illustration in Fig. 15 is only schematic.

Material examined.

See the type.

20. Laboulbenia lecoareri (Balazuc) Huldén stat. nov. Laboulbenia subterranea subsp. lecoareri Balazuc 1974, in Balazuc 1973-74, vol. 43:306.

This taxon is well delimitated and it is quite safe to treat it as a separate species. It is apparently monophagous on Trechus micros (Herbst). The Norwegian specimens were smaller $(330-470 \mu \mathrm{m}$ in length) than the French material (525 $\mu \mathrm{m}$ in length according to Balazuc 1973-74) but otherwise they are similar.

Material examined

*Norway. Sör-Tröndelag: Kvål (Trechus micros).

General distribution

Federal Republic of Germany, France, Hungary, Poland, United Kingdom (Balazuc 1973-74).

Host

Trechus micros (Herbst) (Coleptera, Carabidae).

21. Laboulbenia luxurians

Laboulbenia luxurians Peyritsch 1873:248.

This species was originally described from Austria on Bembidion varium (Oliver) (Coleoptera, Carabidae). Later authors have reported it from many regions and numerous host species (Thaxter 1896, Baumgartner 1923, Siemaszko \& Siemaszko 1928, Briedis 1932, Colla 1934, Banhegyi 1949, Maire 1920). My material of Laboulbenia from $B$. dentellum (Thunberg), a species reported as host for $L$. luxurians, is different from that found on B. varium and it is described as L. marvinii n.sp. in this paper. Since it is probable that these two Laboulbenia species have been mixed under the name $L$. luxurians, I think it is best to give an improved description of $L$. luxurians according to material from $B$. varium.

Receptacle. Pale brown, cell I nearly hyaline in basal part and with a black spot in upper part on appendage side (not mentioned by previous authors!). Small, dark and rounded-elongated dots on cells I-VI and base of perithecium. Cells I-II forming a stalk $80-$ $90 \mu \mathrm{m}$ in length, broadening upwards from $15 \mu \mathrm{m}$ to about $35 \mu \mathrm{m}$ in width. Cells I and II about equal in length or cell II slightly shorter than cell I. Cells 


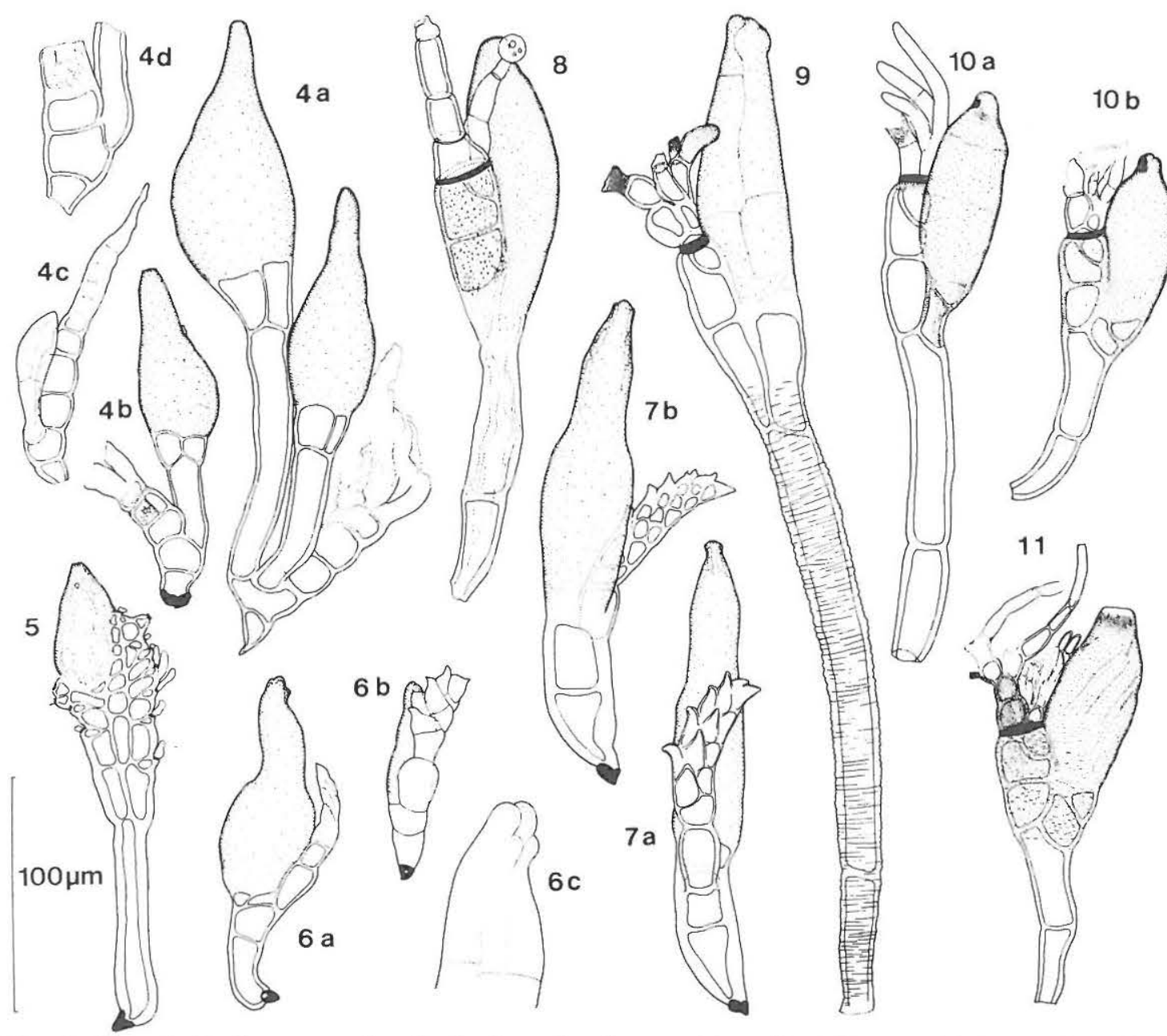

Figs. 4-11. - 4: Cantharomyces orientalis, a)-c) on Carpelimus corticinus, d) on C. opacus. Mature specimens from a) Ytyk-Haja (Yakut A.S.S.R.), b) Nikolsk (Yakut A.S.S.R.), c) immature specimen from Ytyk-Haja, d) base of thallus showing position of compound antheridium (Switzerland). - 5: Rickia wasmannii on Myrmica sabuleti (Yugoslavia). - 6: Stigmatomyces ptilomyiae on Atissa pygmaea (Azores), a) mature specimen, b) immature specimen, c) apex of perithecium. - 7: Stigmatomyces trianguliapicalis on Parydra coarctata (Canary Islands), a)-b) two mature specimens in different views. - 8: Laboulbenia thaxteri on Asaphidion flavipes (Latvian S.S.R.). - 9: Laboulbenia picardii on Tachys bisulcatus (Lebanon). - 10: Laboulbenia nebriae on Nebria rufescens from a) Krasnoyarsk Region, b) United Kingdom. - 11: Laboulbenia ishikawai on Diplous depressus (Khabarovsk Region).

III-V forming a compact group of cells, $40-45 \mu \mathrm{m}$ in length, $35 \mu \mathrm{m}$ in width. Cell III rather flat and obliquely placed against base of perithecium, narrowly connected with cell V. Cell V nearly spherical, about $20 \mu \mathrm{m}$ in width. Cell VI rather flat. Septa II-III and II-VI about equal in length.

Appendages. Insertion cell externally very weakly pigmented with brown, darkest at lower margin and near perithecium. Basal cell of outer appendage rather robust, pale brown, more strongly pigmented along outer margin; second cell nearly black along outer margin. Outer appendage seems to be strongly branched from second cell upwards. Basal cell of inner appendage irregularly triangular; branches (2-4 together) arising from several isodiametric cells on the basal cell. Branches of inner appendage directed inwards on each side of perithecium, probably terminating in antheridia.

Perithecium. Pale brown-olivaceous brown, not or only slightly darker than receptacle. A slightly darker shade around the perithecium below the blunt tip. Perithecium slightly inwards curved. Size $30-40 \times$ $80-100 \mu \mathrm{m}$. Spores at least $30 \mu \mathrm{m}$ in length, but not yet ripe; according to Thaxter (1896), they are about $50 \mu \mathrm{m}$ in length.

Total length from base of foot to tip of perithecium 
about $200-210 \mu \mathrm{m}$.

Host. Bembidion varium (Olivier) (Coleoptera, Carabidae). The parasite grows on the pronotum and elytra of the host.

It is possible that $L$. luxurians is more restricted in its choice of host species than has previously been realized. For the separation of $L$. luxurians from $L$. marvinii, see under the latter species. Some forms of $L$. pedicellata may resemble $L$. luxurians but differ distinctly in the arrangement of cells III-V (see Figs. $23 \mathrm{a}-\mathrm{g}$ ).

The specimens illustrated by Spegazzini (1914, Figs. $18 \mathrm{a}-\mathrm{b}$ ) are not $L$. luxurians althought occurring on $B$. varium; they possibly represent young $L$. vulgaris. Material examined

*Czechoslovakia. Slovakia: Cenke (B. varium). Federal Republic of Germany. Lüneburg (B. varium). *U.S.S.R. Kazachstan: Kazalinsk by Syr Darya (B. varium).

General distribution

According to records of occurrences on Bembidion varium, found at least in Algeria (Maire 1920), Austria (Peyritsch 1873), Hungary (Banhegyi 1949) and Italy (Colla 1934). Reports from other host species must be rechecked.

22. Laboulbenia luxurians subsp. immaculata Huldén n.subsp.

Sine maculis. Matrix: Bembidion semipunctatum (Donovan).

Resembles Laboulbenia luxurians but lacks the distinct black spot in upper part of cell I. The thallus is also slightly smaller, about $135-190 \mu \mathrm{m}$ in length. Spores $37-40 \mu \mathrm{m}$ in length.

Host. Bembidion semipunctatum (Donovan)

(Coleoptera, Carabidae).

Holotype. Slide L. Huldén 28, in MZH. Collecting data of the host: U.S.S.R. Leningrad Region: Molodežnoe (Vammeljoki), leg. W. Hellén.

Although this morph is very similar to L. luxurians, I think it is quite safe to regard it as a separate subspecies, because the difference seems to be constant. Specimens of L. luxurians from three remote localities were also very uniform in habitus (see under that taxon).

Material examined

*Austria. Vienna. On Bembidion semipunctatum. *U.S.S.R. Leningrad Region: Molodežnoe (Vammeljoki). On B. semipunctatum.

\section{Laboulbenia marvinii Huldén n.sp.}

- Figs. 19a-d

Ut Laboulbenia luxurians sed major. Matrix: Bembidion spp.

Receptacle. Pale brown-olivaceous brown, lighter near the base. Small round or transversely elongated dark dots on cells II-VI. Cells I-II forming a stalk $100-130 \mu \mathrm{m}$ in length, broadening upwards from $20 \mu \mathrm{m}$ to $45-50 \mu \mathrm{m}$. Cells III $-\mathrm{V}$ about equal in size. Cell V nearly spherical. Cells III and V narrowly connected. Septum II-III distinctly shorter than septum II-VI.

Appendage. The appendages (unfortunately more or less damaged) resemble those of $L$. luxurians, but seem to be less branched; when young the branches are directed inwards towards the perithecium.
Insertion cell externally narrowly darkened.

Perithecium. Olivaceous brown, darker than receptacle, the septa of the wall cells darker brown, brown-black spot below the tip on outer side. Perithecium straight, fairly symmetrical, tip narrow. Size about $60 \times 120 \mu \mathrm{m}$. Spores $55-60 \mu \mathrm{m}$ in length. Total length from base of foot to tip of perithecium $260-290 \mu \mathrm{m}$.

Host. Bembidion starki Schaum and B. dentellum (Thunberg) $(=B$. flammulatum Clairville) (Coleoptera, Carabidae). The parasite grows on the elytra of the host.

Holotype. Slide L. Huldén 29, in MZH. Collecting data of the host (Bembidion dentellum): Federal Republic of Germany. Hamburg, 5.VII.1949.

I have named this species in honour of my friendly guinea-pig, Marvin, who likes to gnaw my illustrations.

The new species differs from L. luxurians in its larger size, the difference in size between septa II-III and II-VI, more pointed perithecium, slightly larger spores and possibly less branched appendages. It is probably closely related to the Holarctic $L$. fumosa Thaxter, occurring on Platynus spp. and Agonum spp. (Coleoptera, Carabidae). The latter species is more strongly pigmented, and has more upright appendage branches and quite different host genera.

$L$. fumosa was reported from Switzerland on Bembidion dentellum and $B$. conforme Dejean by Baumgartner (1923). These records probably concern L. marvinii. Many European records of $L$. luxurians from various Bembidion species may refer to either L. luxurians or L. marvinii.

Material examined

*Austria. Wildshut. (B. starki). *Federal Republic of Germany. Hamburg ( $B$. dentellum). *France. Seine \& Oise: Cerney ( $B$. dentellum).

24. Laboulbenia nebriae

Laboulbenia nebriae Peyritsch 1871:455. - L. alpestris Picard 1913:552.

Material examined

Austria. Hohe Tauern: Gr. Glockner Pass, Hochtor, altitude $2500 \mathrm{~m}$ (Nebria atrata Dejean). *Norway. Sör-Tröndelag: Melhus (Nebria rufescens (Ström)). United Kingdom. Shetland. (N. rufescens). *U.S.S.R. Krasnoyarsk Region: Abakan (N. rufescens).

General distribution

Alaska (Aleutian Islands), Algeria, Austria, Canada, France, Hungary, Italy, Morocco, Poland, Romania, Switzerland, United, U.S.A., Yugoslavia (Hincks 1960, Stadelmann \& Poelt 1962, Balazuc 1973, 1973-74).

Host

Nebria spp. (Coleoptera, Carabidae).

\section{Laboulbenia notiophili}

Laboulbenia notiophili Cépède \& Picard 1909:259.

Material examined

*Norway. Hordaland: Asköy (Notiophilus biguttatus (Fabricius)).

General distribution

Federal Republic of Germany, Finland, France, Hungary, Poland, Spain, Switzerland (Huldén 1983).

Host

Notiophilus spp. (Coleoptera, Carabidae). 


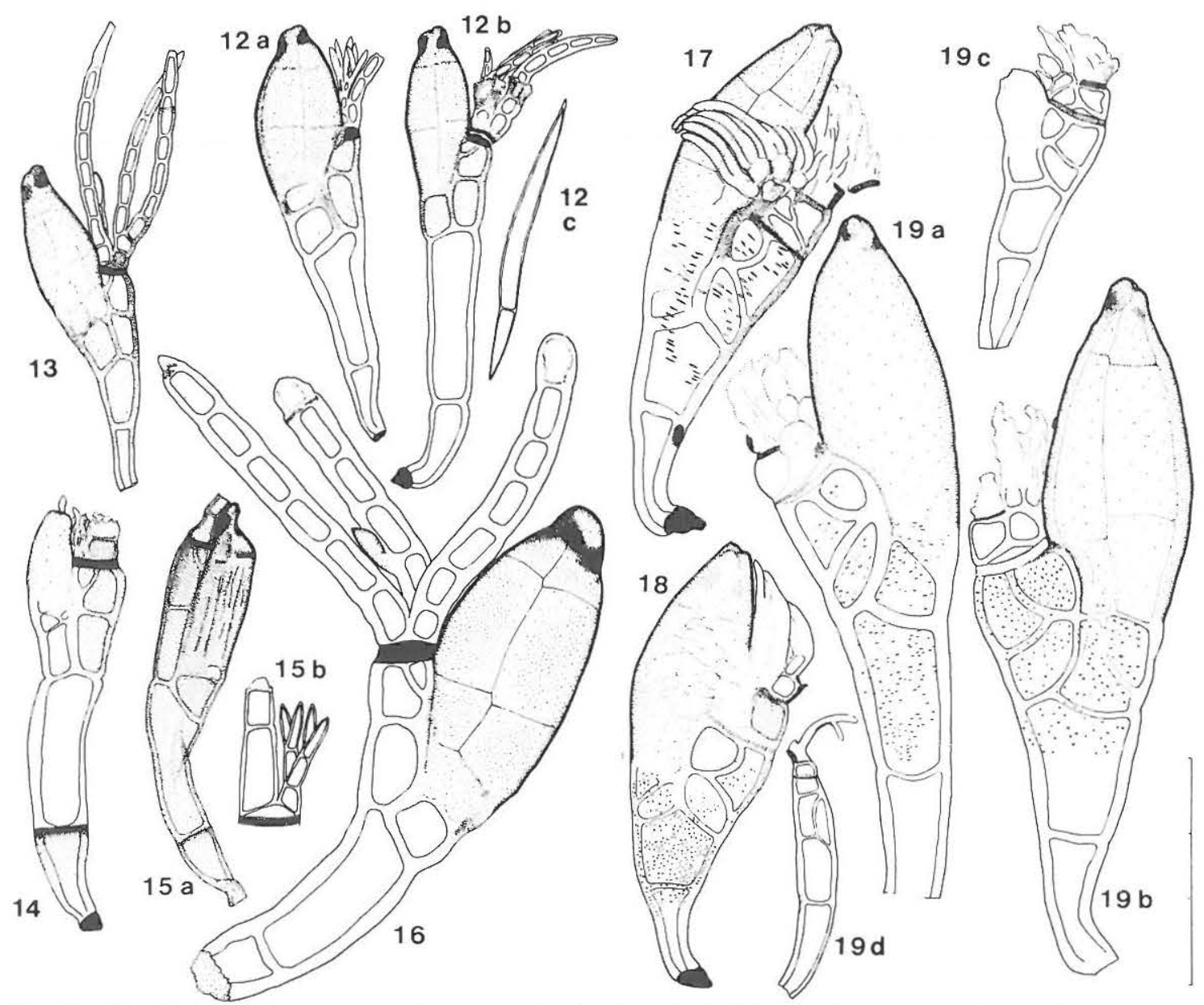

Figs. 12-19. - 12: Laboulbenia eubradycelli n.sp. a) on Bradycellus ruficollis (Finland), b) holotype on Bradycellus caucasicus (Finland), c) spore (from holotype). - 13: Laboulbenia rougetii on Brachinus crepitans (Austria). - 14: Laboulbenia shanorii, immature specimen on Neotrechus suturalis ssp. otiosus (Yugoslavia). - 15: Laboulbenia kobilae n.sp. on Neotrechus suturalis ssp. suturalis (Yugoslavia), a) holotype, b) schematic illustration of the appendages. - 16: Laboulbenia broscosomae n.sp. on Broscosoma baldense (Italy), holotype. - 17: Laboulbenia luxurians on Bembidion varium (Czechoslovakia). 18: Laboulbenia luxurians subsp. immaculata n. subsp. on Bembidion semipunctatum (Leningrad Region), holotype. 19: Laboulbenia marvinii, a) and d) on Bembidion starki (Austria), b) and d) young specimens. - Scale: $40 \mu \mathrm{m}$ (Fig. 12c), $100 \mu \mathrm{m}$ (Figs. 16-19) and $200 \mu \mathrm{m}$ (Figs. 12a-b, 13-15).

\section{Laboulbenia paradoxa Laboulbenia paradoxa Spegazzini 1915b:58}

My material of this species is slightly overmature and the tip of the perithecium is somewhat damaged. The size of the spores is $5 \times 62 \mu \mathrm{m}$. The habitus of the appendages is very characteristic. The species was described from Bembidion nitidulum (Marsham).

Material examined

*Austria. Kärnten, on Bembidion modestum (Fabricius).

General distribution

Italy (Spegazzini 1915b).

Host

Bembidion modestum and B. nitidulum (Coleoptera, Carabidae).
27. Laboulbenia pedicellata

Laboulbenia pedicellata Thaxter 1892:44.

The parasite occurring on the genus Tachys s.lat. and previously interpreted by several authors as $L$. pedicellata actually belongs to L. egens Spegazzini (see under that species). The remaining material om Bembidion s.lat. and Dyschirius spp. is still very heterogeneous. In some cases the general morphological characters seem to be very similar, but considerable variation occurs in spore size. In others distinctly different morphs can be found on the same host individual.In certain cases, however, parasites on a particular host collected from very remote localities may be nearly identical. This has convinced me that $L$. pedicellata s.lat. consists of many taxa. 
Although the separate morphs are not yet safely separable, I here present characters for some diffuse morph-groups that may help future studies on this problem. In the list of material L. pedicellata is still interpreted in a broad sense.

Morph-group 1. Cells I-II forming a slender, evenly broad stalk with little pigmentation, perithecium rather small and narrow. Spore size $35 \mu \mathrm{m}$ (on Bembidion quadrimaculatum) $40 \mu \mathrm{m}$ (B. doris) and $45-50 \mu \mathrm{m}$ (B. gilvipes). In typical cases the total length of the thallus is about $300 \mu \mathrm{m}$, but on $B$. gilvipes I also found short specimens, which may look like members of the next morph-group, but differing in the evenly broad stalk. The typical $L$. pedicellata, as described by Thaxter (1892), belongs to this group. (Fig. 23f, see also Fig.77d in Huldén 1983).

Morph-group 2. Cells I-II forming an only slightly pigmented stalk, which broadens strongly upwards, perithecium short and broad appearing swollen), septum II-III distinctly shorter than septum IIVI, spores about $35-40 \mu \mathrm{m}$ in length, total length of thallus at most about $170 \mu \mathrm{m}$. Specimens from Bembidion quadrimaculatum (Finland and Siberia) were $150-170 \mu \mathrm{m}$ in length, and from $B$. azurescens (France) about $115 \mu \mathrm{m}$ in length. The specimens from $B$. quadrimaculatum greatly resemble the American L. bembidio-palpi Benjamin (in Benjamin \& Shanor 1952), and are possibly conspecific (Fig. $23 \mathrm{~g}$, see also Figs. $77 a-b$ in Huldén 1983).

Morph-group 3. Cell II with a distinct pale constriction, which contrasts with the adjoining rather strongly pigmented areas above and below, perithecium rather narrow, pigmentation in general fairly strong, spore length varying from $30 \mu \mathrm{m}$ to about $45 \mu \mathrm{m}$. Total length $160-250 \mu \mathrm{m}$. A large number of host species: at least $B$. aeneum, $B$. bigutiatum, $B$. harpaloides, $B$. iricolor, $B$. octomaculatum, B. pygmaeum, B. lunulatum and Dyschirius spp. L. tapirina Benjamin (in Benjamin \& Shanor 1952) and possibly L. gracilipes Cépède \& Picard (1908) belong to this group. (Figs. 23a-c, see also Fig. 77e in Huldén 1983).

Morph-group 4. Like the preceding group, but perithecium broader and more robust. Spore length from $40-55 \mu \mathrm{m}$. The largest spores found on specimens from $B$. ruficolle. Cell VI isodiametric or slightly elongated, except in specimens from $B$. ruficolle, where it was flat. Total length $190-230 \mu \mathrm{m}$. A specimen from $B$. articulatum was illustrated in Huldén (1983, Fig. 77c), but pigmentation was not indicated, for pigmentation, see Fig. 23b (belonging to the preceding group) in this paper. Found on the following hosts: $B$. articulatum, $B$. varium and $B$. ruficolle.

Morph-group 5. Stalk without pale constriction on cell II and only a little pigmentation near septum I-II, broadening upwards to a variable degree, the stalk being either slender or robust, perithecium rather big and clumsy, insertion cell strongly constricted. Cell VI variable, rather flat - elongated. Total length $(130-) 200-250 \mu \mathrm{m}$. Specimens referable to this group found on $B$. lunulatum (Turkey), B. aeneum (Netherlands, Sweden), B. semipunctatum (Leningrad Region, Austria) B. inoptatum and B. guttula. The specimen from $B$. inoptatum represents a very short form. (Figs. 23d-e).

Within the groups occur morphs which are very uniform on certain host taxa collected from localities in different regions. These possible represent separate species. The morphs in group 3 seem to be more uniform on Dyschirius species than on Bembidion species, a fact which makes it seem possible that this material could be separated from the rest of $\mathrm{L}$. pedicellata. More investigations are needed before definite conclusions can be made.

Material examined

Austria. Hofgastein (Dyschirius angustatus (Ahrens)). Vienna (Bembidion octomaculatum (Goeze), B. semipunctatum (Donovan)). - Donau-Au ( $B$. inoptatum Schaum). Egypt. Luxor (D. lafertei Putzeys). Federal Republic of Germany. Hamburg (B. guttula (Fabricius), D. thoracicus (Rossi), D. obscurus (Gyllenhal)). - Einbech (B. biguttatum (Fabricius)). - Sylt ( $B$. aeneum Germar). - Ellwangen ( $B$. lunulatum (Fourcroy)). - Zeltberg bei Lüneburg (B. varium (Olivier)). France. Gascogne (B. articulatum (Panzer)). Allier: Vichy (B. articulatum). - 'La Chapelle' (B. azurescens (Dalla Torre)). Greece. Elevsis (B. iricolor Bedel). - Crete: Canea (B. lunulatum). *Ireland. Kerry: Killarney ( $B$. harpaloides Audinet-Serville). Netherlands. Amsterdam ( $B$. aeneum). ${ }^{*}$ Sweden. Skåne: Arlöv (B. aeneum). Lomma ( $B$. aeneum, $D$. globosus (Herbst)). - Öland: Vickleby (B. aeneum). Kalla (B. aeneum). - Gotland (D. globosus). *Turkey. Smyrna (B. lunulatum). U.S.S.R. Leningrad (D. globosus). - *Pskov Region: Pechory (D. globusus). Latvian S.S.R.: Riga (D. thoracicus). Sigulda (D. thoracicus). - *Azerbaijan: near Lenkoran (D. globusus). *Uzbekistan: Syr Darya Region, Golodnaja Step (D. syriacus Putzeys). - *Krasnoyarsk Region: Yeniseysk (B. quadrimaculatum (Linnaeus)). — *Irkutsk Region: Sujetuk (B. quadrimaculatum). - *Yakut A.S.S.R.: Lena River (mouth of Aldan River) (D. septentrionum Munster).

\section{General distribution}

Apparently cosmopolitan, in Europe known from Austria, Belgium, the Federal Republic of Germany, Finland, France, Greece, Hungary, Italy, the Netherlands, Poland, Romania, Spain, the United Kingdom, the U.S.S.R. (Leningrad Region, Karelian A.S.S.R., Archangel Region, Latvian S.S.R.) (Huldén 1983).

Host

Dyschirius, Bembidion and some other genera (Coleoptera, Carabidae).

\section{Laboulbenia philonthi}

Laboulbenia philonthi Thaxter 1893:174.

Material examined

*Austria. Ober-Österreich: Linz (Philonthus cf. micans (Gravenhorst)). Tirol: Schlegeis ( $P$. quisquiliarius (Gyllenhal)).

General distribution

Argentina (Spegazzini 1912), Federal Republic of Germany (Scheloske 1969), France (Balazuc 1973-74), Italy (Rossi 1975), Poland (Majewski 1973) and U.S.A. (Thaxter 1893).

\section{Host}

Philonthus (s.lat.) (Coleoptera, Staphylinidae).

\section{Laboulbenia picardii \\ Laboulbenia picardi Maire 1916:28. \\ Material examined \\ *Lebanon. Mont Baruk (Tachys bisulcatus (Nicolai)). General distribution}

Algeria, Greece, Italy (Rossi 1975). 

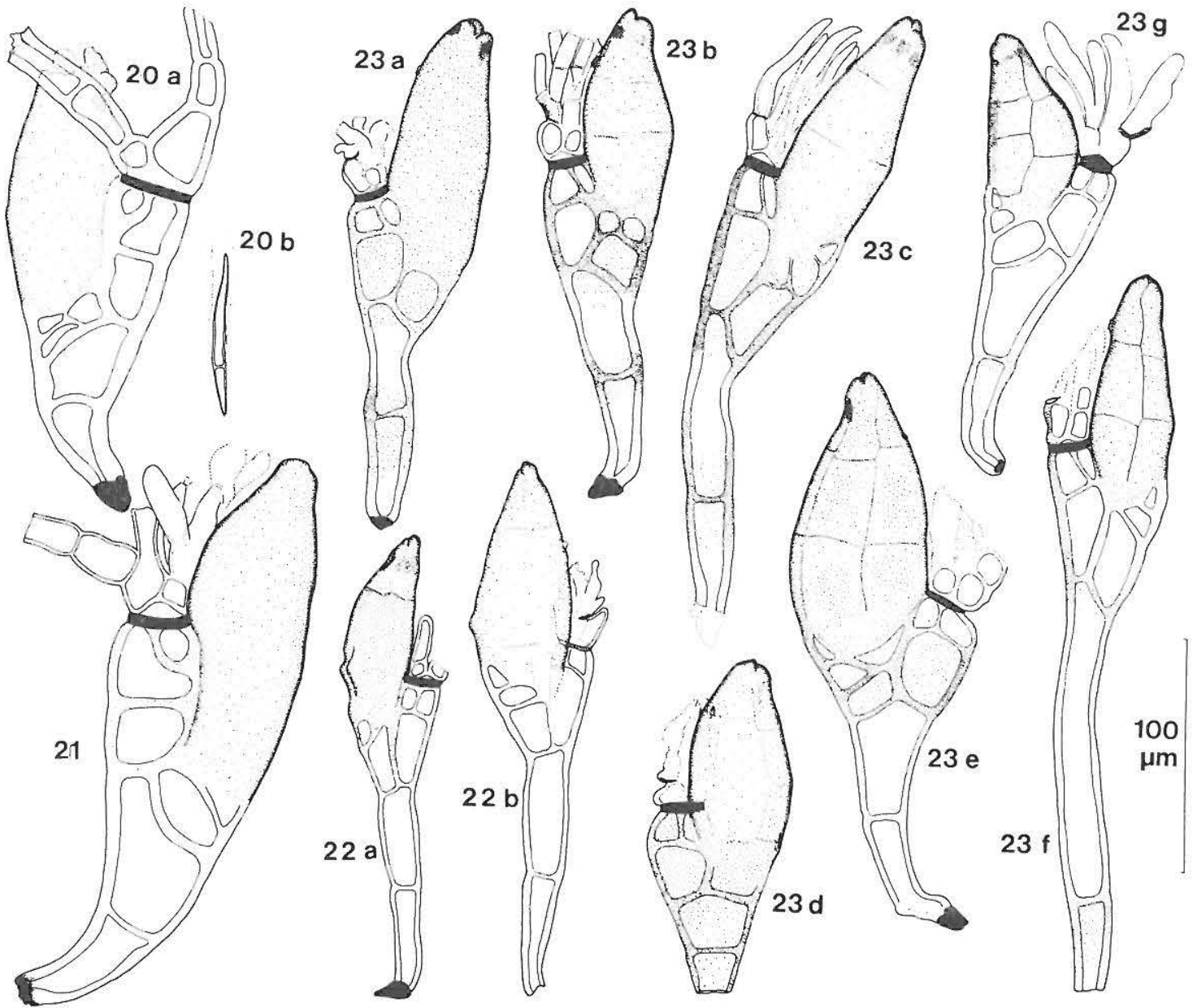

Figs. 20-23. - 20: Laboulbenia paradoxa, a) mature specimen with slightly broken perithecium, b) spore. - 21: Laboulbenia vulgaris on Pelophila borealis (Krasnoyarsk Region). - 22: Laboulbenia egens, a) on Tachys haemorrhoidalis (Canary Islands), b) on Tachys fumigatus spp. socius (Egypt). - 23: Laboulbenia pedicellata s.lat. on a) Bembidion aeneum (Sweden), b) B. aeneum (Federal Republic of Germany), c) B. iricolor (Greece), d) B. inoptatum (Austria), e) B. guttula (Federal Republic of Germany), f) and g) B. quadrimaculatum (Irkutsk Region).

Host

Tachys bisulcatus (Coleoptera, Carabidae).

30. Laboulbenia polyphaga Laboulbenia polyphaga Thaxter 1893:165.

\section{Material examined}

Austria. Obertilliach (Calathus melanocephalus (Linnaeus)). *Faeroes (Denmark). Vagur: Sörvagur (C. fuscipes (Goeze)). *Norway. Möre og Romsdal: Molde (C. micropterus Duftschmid). Switzerland. Munstertal, Santa Maria ( $C$. melanocephalus). U.S.S.R. *Archangel Region: Mesen ( $C$. melanocephalus). - *Caucasus ( $C$. melanocephalus).

\section{General distribution}

Cosmopolitan, in Europe Known from Austria, Belgium, the Federal Republic of Germany, Finland, France, Hungary, Italy, the Netherlands, Poland, Portugal, Switzerland, the U.S.S.R. (Leningrad Region, Latvian S.S.R.) (Huldén 1983).
Host

Calathus, Acupalpus and some other genera (Coleoptera, Carabidae).

31. Laboulbenia pseudomasei

Laboulbenia pseudomasei Thaxter 1899:196

Material examined

*Bulgaria. Rila (Pterostichus strenuus (Panzer)). France. Pyrenees: Porté Puymorens ( $P$. strenuus). *Sweden. Skåne: Angelholm ( $P$. strenuus). - Gotland: Klinte $(P$. strenuus $)$. U.S.S.R. *Archangel Region: Mesen ( $P$. brevicornis (Kirby)). - ${ }^{*}$ Caucasus $(P$. strenuus $)$. — *Yakut A.S.S.R.: Bardeljak (P. ochoticus Sahlberg). Agrafena (P. ochoticus). Shigansk ( $P$. ochoticus var. mutator Poppius). Tungus-Haja ( $P$. brevicornis). - 'Sibir. or.' (P. empetricola Dejean).

General distribution

Federal Republic of Germany, Finland, France, Hungary, Italy, Mongolia, Poland, Switzerland, U.S.S.R. (Karelian A.S.S.R.) (Huldén 1983). 
Host

Pterostichus spp. and Anisodactylus spp. (Coleoptera, Carabidae).

\section{Laboulbenia rougetii}

Laboulbenia rougetii Montagne \& Robin in Robin 1853:622.

\section{Material examined}

Austria. Neusiedler See (Brachinus crepitans (Linnaeus)).

General distribution

Holarctic, Hong Kong (Stadelmann \& Poelt 1962, Sugiyama 1973, Balazuc 1973-74).

Host

Brachinus, Chlaenius and some other related genera (Coleoptera, Carabidae)

\section{Laboulbenia shanorii \\ Laboulbenia shanorii Banhegyi 1960:54.} - Fig. 14 (immature specimen)

Material examined

Yugoslavia. Montenegro: Krivosije (Neotrechus suturalis ssp. otiosus Obenb.).

General distribution

Albania, Yugoslavia (Banhegyi 1960).

Host

Neotrechus spp. (Coleoptera, Carabidae).

\section{Laboulbenia thaxteri}

Laboulbenia thaxteri Cépède \& Picard 1908:260.

\section{Material examined}

*Austria. Graz (A. flavipes), *U.S.S.R. Latvian S.S.R.: Sigulda (Asaphidion flavipes (Linnaeus)).

General distribution

Algeria (Maire 1920), France (Cépède \& Picard 1908), Greece (Balazuc 1973-74), Italy (Colla 1934), Poland (Siemaszko \& Siemaszko 1928), Switzerland (Baumgartner 1951).

Host

Asaphidion spp. (Coleoptera, Carabidae).

\section{Laboulbenia vulgaris}

Laboulbenia vulgaris Peyritsch 1873:248.

- Fig. 21

The illustrated specimen from Pelophila borealis is a morph with exceptional appendages. It very probably belongs to the $L$. vulgaris complex.

\section{Material examined}

*Albania. Korab (Bembidion balcanicum Apfelbeck). Algeria. Constantine (B. quadripustulatum Audinet-Serville). Austria Salzburg: Bad Gastein (B. stomoides Dejean). Schafberg (Trechus wagneri Ganglbauer). - Tirol: Reutte ( $B$. longipes Daniel). Lienz ( $B$. longipes). Without locality ( $B$. tricolor (Fabricius)). - Kärnten: Eisenkappel (B. millerianum Heyden). Vorarlberg: Riezlern (B. ruficorne Sturm). - OberÖsterreich: Wildshut (B. starki Schaum). Ostermiething ( $T$. discus (Fabricius)). - Nieder-Österreich: Raxalpe (T. ovatus Putzeys). - Vienna (B. seminpunctatum (Donovan), $B$. lunatum (Duftschmid)). - Steiermark: Admont (B. conforme Dejean, B. testaceum ssp. testaceum (Duftschmid), B. tricolor Fabricius). Schneealm ( $T$. ovatus). Graz (B. schueppeli Dejean). Dackstein, Gutenberghaus ( $T$. glacialis Heer). Gesäuse (B. ruficorne, T. ovatus). - Hohe Tauern: Hallbrünn ( $T$. hampei Ganglbauer). Salesenwald ( $T$. glacialis). *Azores. Flores ( $B$. harpaloides Audinet- Serville). Bulgaria. Rila mountains (B. tibiale (Duftschmid). B. millerianum, B. eques ssp. combustum Ménétries). Canary Islands (Spain). Gran Canaria (B. subcallosum Wollaston). - Gomera (B. atlanticum ssp. phobon Netolitzky). - Tenerife (B. fortunatum Wollaston, $B$. atlanticum ssp. phobon). Czechoslovakia. Bohemia: Pardubice (B. fluviatile Dejean). Without locality $(B$. ascendens Daniel, $B$. nitidulum (Marsham)). - Moravia: Paskau (B. tricolor). - Slovakia: Tatra, Banská Bystrica ( $B$. difficile ssp. haeneli Netolitzky). Fatra, Kriván (Duvalius microphthalmus ssp. microphthalmus (Miller)). Silica (D. microphthalmus ssp. hungaricus Csiki). Zádiel dol. (B. subcostatum ssp. javurcovae Fassati). *Faeroes (Denmark). Suduroy: Nes (T. obtusus Erichson). Federal Republic of Germany. Hamburg (B. tetracolum ssp. tetracolum Say, B. punnctulatum ssp. punctulatum Drapiez, $B$. bipunctatum (Linnaeus)). Hanau, Main (B. tetracolum ssp. tetracolum). Marburg (B. fluviatile Dejean). Einbech ( $B$. biguttatum (Fabricius)). Baden-Würtenberg, Ulm (B. schueppeli Dejean). Bonn (B. tetracolum ssp. tetracolum). Bayrischen Alpen (B. conforme Dejean). France. Corsica (B. kuesteri Schaum). Corsica, Vizzarona, $1200 \mathrm{~m}$ (B. geniculatum ssp. dilutipes Deville). Corsica, Ajaccio ( $B$. obtusus ssp. tethys Netolitzky). Allier, Abrest (B. punctulatum ssp. punctulatum). Allier, Vichy (B. coeruleum AudinetServille, $B$. azurescens $\mathrm{H}$. Wagner). Paris (B. coeruleum). Strasbourg ( $B$. prasinum (Duftschmid)). Beaugency ( $B$. punctulatum ssp. punctulatum). Polminhac (B. punctulatum ssp. punctulatum). Gennevilliers, Seine (B. tetracolum ssp. tetracolum). 'Gallia' (B. genei ssp. illigeri Netolitzky). ${ }^{*}$ German Democratic Republic. Leipzig (B. biguttatum). *Greece. Corfu (B. nigropiceum (Marsham)). Lesbos (B. punctulatum ssp. punctulatum). Nauplia (B. tetracolum ssp. tetracolum). *Ireland. Kerry: Killarney (B. tetracolum ssp. tetracolum, B. harpaloides). - Cork: Mallow (B. tetracolum ssp. tetracolum). Italy. Sardinia (T. rufulus Dejean). Sardinia, Tempio (B. elongatum ssp. elongatum Dejean). Mte Baldo (T. longobardus, T. sinuatus ssp. sinuatus Schaum). Bergamo, Pellegrino (B. ascendens). Val Giudica ( $T$. longulus ssp. danieli Holdhaus). Bolzano, Tires (B. tricolor). Mte Maggiore (Anophthalmus schmidti ssp. flachi Winkler). Val Camonica, Edolo (B. geniculatum Heer). Val Camonica, Oglia ( $B$. tricolor). Cuneo, Crissolo ( $B$. longipes). Genova, Ronco Scrivia ( $B$. ascendens). *Madeira (Portugal). Paul da Serra (B. obtusum ssp. tethys). Porto Santo (B. atlanticum ssp. atlanticum). *Morocco. Haute Atlas: Arround (B. atrocoeruleum Stephens, $B$. siculum ssp. siculum Dejean, $B$. coeruleum, B. dalmatinum ssp. dudichi Csiki). Amizmiz (B. coeruleum). Reraia (B. coeruleum). Netherlands. Rotterdam (B. tetracolum ssp. tetracolum). *Norway. Hordaland: Gjerstad (B. bruxellense). *Palestine. Galilee (B. tetracolum ssp. tetracolum). Poland. Koszalin ( $B$. biguttatum). Krościenko (B. lomnickii Netolitzky). Romania. Transylvania (Duvalius procerus Putzeys). Spain. Madrid. (B. paulinoi Heyden). Sierra Nevada (B. atrocoeruleum). *Sweden. Skåne: Arlöv (B. tetracolum ssp. tetracolum). Ven (B. stephensi Crotch). - Västergötland: Alingsås ( $B$. mannerheimi Sahlberg). Switzerland. Münstertal (B. tricolor, B. conforme, $B$. complanatum Heer, B. ruficorne Sturm, B. andrea ssp. bualei Duval). Unter-Engadin, Zernez ( $B$. andreae ssp. bualei, $B$. geniculatum). Chiasso, Tessin (B. coeruleum). Solothurn, Dornach $(B$. ascendens, $B$. andreae ssp. bualei, $B$. decorum ssp. decorum, B. punctulatum ssp. punctulatum). Wallis, Gletsch Furka (B. ruficorne). Uri, Schächen-Tal (B. millerianum Heyden). Uri, Oberalppass ( $B$. incognitum Müller). Wallis, Bivuntal (B. complanatum). No locality ( $B$. complanatum). *Syria. Sanamein ( $B$. quadripustulatum Audinet-Serville, $B$. tetracolum ssp. tetracolum). Turkey. Ephesos (B. praeustum). Hermos River (B. tetracolum ssp. tetracolum, B. moschatum). Smyrna (B. dalmatinum ssp. dalmatinum). Tschakit-Thal ( $B$. andreae ssp. caucasicola Netolitzky). Baba Dagh (B. cordicolle Duval, B. praeustum). United Kingdom. Scotland, Dumfriesshire (B. decorum ssp. 
decorum). Shetland ( $T$. obtusus). Orkney (B. tibiale (Duftschmid), B. tetracolum ssp. tetracolum). U.S.S.R. *Archangel Region: Mesen (B. guttula). Pjosa ( $B$. andreae ssp. polonicum Müller, B. semipunctatum (Donovan)). *Armenia: Zsachkadzor (B. testaceum ssp. parallelipenne Chaudoir, B. keilbachi Müller, B. tibiale, B. geniculatum Heer). - *Azerbayjan: Lenkoran ( $B$. andreae ssp. quadriflammeum Reitter). - *Turkmenistan: Ashkhabad ( $B$. tetracolum ssp. tetracolum). - ${ }^{*}$ Kirgizia: Dschil-Aryk ( $B$. giganteum Sahlberg, B. insidiosum Solsky). - *Tomsk Region: Schukova (B. tetracolum ssp. tetracolum). *Krasnoyarsk Region: Dudinka (Pelophila borealis Paykull). Osnatschennaja (B. petrosum ssp. petrosum Gebler). *Yakut A.S.S.R.: Olekminsk (B. hirmocaelum Chaudoir). Yakutsk (B. bruxellense Wesmael). Ytyk-Haja (B. poppii Netolitzky). Shigalovo (B. hirmocaelum). Shigansk (B. bruxellense, $B$. obscurellum (Motschulsky)). Batylim (Trichocellus mannerheimi ssp. mannerheimi (F. Sahlberg)). Bulun ( $B$. difforme Motschulsky). Yugoslavia. Carniolia ( $B$. elongatum ssp. tarsicum Peyron). Carniolia, Cerna prst (Anophthalmus bohimiensis Ganglbauer). Dalmatia (B. dalmatinum ssp. dalmatinum Dejean). Montenegro, Uruja (B. tricolor). Bosnia-Herzegovina (B. ruficorne). BosniaHerzegovina, Vran Planina (B. reiseri ssp. reiseri Apfelbeck, $B$. reiseri ssp. vranense Apfelbeck).

\section{General distribution}

Cosmopolitan (Huldén 1983).

\section{Host}

Bembidion (s.lat.) and some related genera (Coleoptera, Carabidae).

\section{Misgomyces dyschirii}

Misgomyces dyschirii Thaxter 1900:443.

Material examined

*Austria. Neusiedler See (Dyschirius extensus Putzeys, D. pusillus (Dejean)). *Canary Islands (Spain). Gran Canaria: Pt. Maspalomas (D. pusillus). *Denmark. Själland: Saltholmen (D. salinus Schaum). France. Allier: Vichy (D. nitidus (Dejean)). 'Germania'. No locality, on D. intermedius Putzeys. *Greece. Corfu (D. salinus). *Iran. Lotfabad (D. politus (Dejean)). "Ireland. Kerry: Killarney (D. globosus (Herbst)). Italy. Ancona reg.: Ancona (D. digitatus (Dejean)). - Basilicata reg.: San Basilio (D. laeviusculus Putzeys). Lago Trasimeno (D. alpicola Ganglbauer). *Palestine. Kison, near Haifa (D. rufoaeneus Chaudoir). - Jordan, near Jericho (D. rufoaeneus). Spain. Algeciras (D. numidicus Putzeys). U.S.S.R. Leningrad (D. globosus). - *Estonian S.S.R.: Haapsalu r., 'Nuckö' (D. globosus). Tartu r., Tartu ( $D$. globosus). - * Latvian S.S.R.: Sigulda (D. globosus). Jugla (D. globosus). - *Ukraine: Odessa (D. substriatus ssp. priscus Müller). Bogdo (D. nitidus). — *Turkmenistan: Michailovsk (D. salinus). Tedzhen (D. nitidus). - *Buryatian A.S.S.R.: Ubukunsk (D. globosus).

\section{General distribution}

Algeria, Federal Republic of Germany, Finland, France, Hungary, Italy, Japan, Netherlands, Poland, Romania, Spain, Switzerland, United Kingdom, U.S.A., U.S.S.R. (Leningrad Region) (Bechet \& Bechet 1960, Balazuc et al. 1983, Huldén 1983).

Host

Dyschirius spp. (Coleoptera, Carabidae).

\section{Monoicomyces furcatus}

Monoicomyces furcatus Thaxter 1931:41.

Material examined

"Czechoslovakia. Bohemia (Oxytelus laqueatus (Marsham)).

*Norway. Dovre: Fokstua (O. laqueatus). *'Sweden. Öland: Vickleby $(O$. laqueatus).
General distribution

Finland, Haiti, Jamaica, Poland, U.S.S.R. (Leningrad Region, Karelian A.S.S.R., Murmansk Region) (Huldén 1983).

\section{Host}

Oxytelus laqueatus (Coleoptera, Staphylinidae) in Europe (Huldén 1983).

\section{Monoicomyces sanctae-helenae}

Monoicomyces sanctae-helenae Thaxter 1900:413.

The present material represents the typical morph (cf. Huldén 1983).

Material examined

U.S.S.R. Southern Urals, locality unknown (Oxytelus piceus (Linnaeus)). — *Yakut A.S.S.R.: Olekminsk (O. piceus).

\section{General distribution}

Algeria, Cameroon, Finland, 'Germany', Italy, Malaysia (Sarawak), Poland, St. Helena, Taiwan, U.S.S.R. (Leningrad Region, Novosibirsk Region) (Huldén 1983).

\section{Host}

Oxytelus spp. (Coleoptera, Staphylinidae).

\section{Peyritschiella protea}

Peyritschiella protea Thaxter 1900:427.

All records on Anotylus rugosus (Fabricius).

Material examined

*Austria. Marburg. *Czechoslovakia. Paskau. France. Seine \& Oise: Cerney. German Democratic Republic. Lübars. *Ireland. Kerry: Killarney. Romania. Transylvania. *Sweden. Skåne: Lomma. Kungsmarken. Bjäred. - Halland: Särö. - Västergötland: Örby. Skövde. United Kingdom. Surrey. - NW Wales. - Shetland. U.S.S.R. *Archangel Region: Archangel.

General distribution

Algeria, Federal Republic of Germany, Finland, France, German Democratic Republic, Hungary, Netherlands, Poland, Romania, United Kingdom, U.S.A., U.S.S.R. (Leningrad Region, Karelian A.S.S.R.) (Balazuc 1973, Huldén 1983).

Host

Anotylus spp., Oxytelus spp., and some related genera (Coleoptera, Staphylinidae).

\section{Rhachomyces aphaenopsis}

Rhachomyces aphaenopsis Thaxter 1905:314.

Material examined

France. Ariège: Grotte Daubert (Aphaenops cerberus (Dieck)).

\section{General distribution}

France (Balazuc 1970), Spain (Balazuc et al. 1983).

Host

Aphaenops spp. Coleoptera, Carabidae).

\section{Rhachomyces furcatus}

Acanthomyces furcatus Thaxter 1893:177. Rhachomyces furcatus (Thaxter) Thaxter 1895:468.

Material examined

Austria. Nieder-Österreich: Alps (Othius brevipennis Kraatz). - Steiermark: Graz (O. brevipennis). ${ }^{*}$ German Democratic Republic. Freienwalde (O. angustus Stephens). *Hungary. No locality indicated $(O$. crassus Motschulsky). *Sweden. Skåne: Balsbergsgrottan (O. punctulatus (Goeze)). Yugoslavia. Bosnia \& Herzegovina: Mostar (O. lapidicola Kiesenwetter). 


\section{General distribution}

Algeria, Austria, 'Equatorial Africa', Federal Republic of Germany, Finland, France, Poland, United Kingdom, U.S.S.R. (Karelian A.S.S.R.), ?Yugoslavia (Frank 1982, Huldén 1983).

Host

Othius spp. (Coleoptera, Staphylinidae).

\section{Rhachomyces hypogaeus}

Acanthomyces hypogaeus Thaxter 1893:177. Rhachomyces hypogaeus (Thaxter) Thaxter 1895:467. Material examined

Yugoslavia. 'Gradah Höhle' (Typhlotrechus bilimeki ssp. bilimeki (Sturm)). - Croatia. Without locality information, on $T$. bilimeki ssp. likanensis Schauf. 'Silna Radino pěc' ( $T$. bilimeki ssp. kiesenwetteri Schmidt).

General distribution

Austria, Yugoslavia (Thaxter 1896, Banhegyi 1960).

Host

Typhlotrechus bilimeki sspp. (Coleoptera, Carabidae).

43. Rhachomyces hypogaeus subsp. richardii

Rhachomyces hypogaeus subsp. richardii Balazuc 1973(42):256 in Balazuc 1973-74. Illustrated in Balazu 1970.

Described on Speotrechus mayeti (Ab.) (+ sspp.) from France.

Material examined

*Italy. Trento: 'Monte Pasi', on Speotrechus knauthi Ganglbauer.

General distribution

France (Balazuc 1970).

Host

Speotrechus spp. (Coleoptera, Carabidae).

\section{Rhachomyces maublancii}

Rhachomyces maublancii Lepesme 1942:73 (nomen nudum). - Rhachomyces maublancii Lepesme ex W. Rossi 1978:329.

Material examined

Italy. Cima Tombea (Duvalius baldensis ssp. tombeanus Ganglbauer). Bergamo: Monte Alben (Duvalius winkleri Jeannel).

General distribution

Italy (Rossi 1978), Hungary (Banhegyi 1949).

Host

Duvalius spp. (Coleoptera, Carabidae).

\section{Rhachomyces ?peyerimhoffii}

Rhachomyces peyerimhoffii Maire 1912:197.

Described from Algeria on Duvalius lapiei (Peyerimhoff). Balazuc (1970) questioned the European records from Hungary and Yugoslavia (cf. Banhegyi 1960). My material consists of only one specimen, which lacks the perithecium. It resembles the illustration of $R$. peyerimhoffii presented by Lepesme (1942, Fig. IV:1). Total length of the receptacle $255 \mu \mathrm{m}$.

Material examined

*Italy. Brescia: Val Camonica, Monte Glisento (Duvalius longhii Comolli).
General distribution

Algeria, ?Hungary, ?Yugoslavia (Balazuc 1970).

Host

Duvalius spp. (Coleoptera, Carabidae).

46. Rhachomyces philonthinus

Rhachomyces philonthinus Thaxter 1900:435.

Material examined

*Austria. Ost-Tirol: in the vicinity of Lienz, altitude $1800 \mathrm{~m}$ and $2100 \mathrm{~m}$ (Philonthus varians (Paykull)).

General distribution

Largely distributed in Europe, Africa, Asia and North America (Balazuc, 1973-74). In Europe recorded from Belgium, the Federal Republic of Germany, France, Hungary, Italy, the Netherlands, Poland, Switzerland and the United Kingdom (Collart 1945, Hincks 1960, Stadelmann \& Poelt 1962, Balazuc 1973-74, Rossi 1975).

Host

Philonthus spp. (Coleoptera, Staphylinidae).

47. Rhachomyces stipitatus Rhachomyces stipitatus Thaxter 1900:438.
Rhachomyces stipitatus var. pallidus Maire 1912:196. - Rhachomyces capucinus Thaxter 1931:276. Synonymy according to Rossi (1978).

Material examined

France. Tarn-et-Garonne: Grotte de Capucin (Duvalius lespesi Fairmaire).

General distribution

Algeria, France, Greece, Italy (Balazuc 1970, Rossi 1978).

Host

Duvalius spp. (Coleoptera, Carabidae).

48. Rhachomyces tenenbaumii

Rhachomyces tenenbaumii Siemaszko \& Siemaszko 1928:205.

The species was described on Thalassophilus longicornis (Sturm) from Poland. Both T. longicornis and $T$. whilei Wollaston are free-living beetles occurring in moist habitats. The former is largely distributed in Europe and the latter restricted to the Canary Islands. A third species, T. breuili (Jeannel), is confined to caves in Spain. The identity of possible parasites on this species would be of great interest; so far none has been found.

Material examined

*Canary Islands (Spain). La Palma: Caldera (Thalassophilus whilei Wollaston), - Gomera: El Cedro (T. whilei).

General distribution

Austria, France, Poland (Banhegyi 1964).

Host

Thalassophilus spp. (Coleoptera, Carabidae).

49. Rhachomyces vayssierei

Rhachomyces vayssierei Lepesme 1942:65.

Material examined

*Austria. Tirol: Hohe Tauern, Gasteiner Tal (Trechus quadristriatus (Schrank)). *German Democratic Republic. Leipzig (Trechus obtusus Erichson). *Sweden. Öland: Högby (T. quadristriatus).

General distribution

Bulgaria, France, Hungary (Banhegyi 1960). 
Host

Trechus spp. (Coleoptera, Carabidae).

\section{Rickia hyperborea}

Rickia hyperborea Balazuc 1980:216.

The find of Rickia hyperborea in Tit-Ary in Yakutia is the northernmost record of Laboulbeniales presently known. The species probably occurs all over the range of Micralymma marinum and its closest relatives.

Material examined

Norway. Troms: Kvesmenes (Micralymma marinum Ström) Maalselv ( $M$. marinum). Hillesöya ( $M$. marinum). U.S.S.R *Yakut A.S.S.R.: Tit-Ary, Lena River, about $72^{\circ} \mathrm{N}$ ( $M$. brevilingue ssp. dicksoni Mäklin).

General distribution

France, Norway, U.S.S.R. (Murmansk Region, Magadan Region) (Huldén 1983).

Host

Micralymma spp. (Coleoptera, Staphylinidae).

\section{Rickia wasmannii}

Rickia wasmannii Cavara 1899:173.

Material examined

*Yugoslavia. Slovenia: Podĉetrtek (Myrmica sabuleti Meinert).

General distribution

Austria, Federal Republic of Germany, France, Italy, Luxemburg, Spain, Switzerland, United Kingdom (Scotland) (Balazuc 1973-74, Balazuc et al. 1982).

Host

Myrmica spp. (Hymenoptera, Formicidae).

52. Stigmatomyces ptilomyiae - Figs. $6 \mathrm{a}-\mathrm{c}$ Stigmatomyces ptilomyiae Thaxter 1931:154.

Material examined

*Azores (Portugal). Fayal: Horta (Atissa pygmaea Haliday). - Terceira: Angra do Heroismo (A. pygmaea).

General distribution

Grenada, Italy, Jamaica (Thaxter 1931, Rossi \& Cesari Rossi 1979).

Hosi

Atissa (Ptilomyia) spp. (Diptera, Ephydridae).

53. Stigmatomyces trianguliapicalis - Figs. $7 \mathrm{a}-\mathrm{b}$ Stigmatomyces trianguliapicalis Majewski 1972:234.

Material examined

* Canary Islands (Spain). Gran Canaria: Los Lagunetas (Parydra coarctata (Haliday))

\section{General distribution}

Italy, Poland (Majewski 1972, Rossi \& Cesari Rossi 1979).

Host

Parydra spp. (Diptera, Ephydridae).

\section{Symplectromyces vulgaris}

Teratomyces vulgaris Thaxter 1900:431. -

Symplectromyces vulgaris (Thaxter) Thaxter 1908:315. Material examined

*Sweden. Skåne: Balsbergsgrottan (Quedius mesomelinus (Marsham)). Tykarpsgrottan (Q. mesomelinus).

General distribution

Belgium, Bengal, Canada, Federal Republic of Germany,
Finland, Hungary, Italy, Netherlands, Portugal, Spain, United Kingdom, U.S.A., U.S.S.R. (Leningrad Region, Murmansk Region), Yugoslavia (Huldén 1983).

Host

Quedius spp. (Coleoptera, Staphylinidae).

Acknowledgements. I am grateful to the following persons for providing material or information essential ot this study: Prof. Harald Haberman (Tartu, Estonian S.S.R.), Dr. Lita Greve Jensen (Bergen, Norway), Prof. Alois Kofler (Lienz, Austria), Mr. Björn Erling Waage (Bergen, Norway), Dr. Dagfinn Refseth (Trondheim, Norway) and Mr. Seppo Koponen (Turku, Finland). Mr. Olav Aas (Bergen, Norway), who has also investigated Laboulbeniales on the insects collected by Björn Erling Waage, kindly gave me permission to publish the results in this connection.

\section{References}

Balazuc, J. 1970: Commentaires sur les Rhachomyces parasites des Trechidae, avec déscriptions de formes nouvelles (Ascomycetes, Laboulbeniales). - Ann. Soc. Ent. Fr. (N.S.) 6(3): 677-699.

- 1971: Notes sur les Laboulbéniales 3. Rectifications, synonymies et mises au point. - Bull. Soc. Linn. Lyon 40: $211-216$

- 1973: Ebauche d'une flore des Laboulbéniales de Roumanie (Ascomycetes). - Livre du Cinquantenaire de l'Institut de Spélèologie 'Emile Racovitza', Bucarest: $463-477$

- 1973-74: Laboulbéniales de France. - Bull. Soc. Linn. Lyon 42: $244-256,280-285,43: 12-21,57-64,73-$ $79,253-262,295,-315,346-368$.

- 1978: Laboulbéniales (Ascomycetes) de la région Française Antilles-Guyane. - Bull. Soc. Linn. Lyon 47: 488-500.

- 1980: Laboulbéniales nouvelles (Ascomycetes), parasites de Coléoptères et de Diptères. - Bull. Mus. Nat. Hist. Nat. $4^{\mathrm{e}}$ ser. (section B) 2(2): 209-219.

- 1982: Laboulbéniales (Ascomycetes) de Madagascar, des Comores et des Mascareignes. - Bull. Soc. Linn. Lyon 51: 6-27.

Balazuc, J., Espadaler, X. \& Girbal, J. 1983: Laboulbenials (Ascomicets) Ibèriques 2. Noves aportacions. - Collnea Bot. 14: 39-42.

Banhegyi, J. 1949: Les Laboulbéniales de la Transylvanie. - Index Horti Bot. Univ. Budapest 7: 93-101.

- 1960: Contributions à la connaissance des Laboulbéniales de la péninsule des Balkans. - Ann. Univ. Sci. Budapest. Sect. Biol. 3: 49-67.

- 1964: Notes sur quelques Laboulbéniales de la Pologne. - Ann. Univ. Sci. Budapest. Rolando Eötvös nomin., Sect. Biol. 7: 19-27.

Baumgartner, R. 1923: Contribution à l'étude des Laboulbéniales de la Suisse. - Jahrb. Philosoph. Fakultät II Univ. Bern 3: 257-265.

- 1951: Résultats de mes dernières récherches sur les Laboulbéniales (Champignons sur insectes vivants). Mitt. Naturforsch. Ges. Bern. Neue Folge 8: xxx-xxxiii.

Bechet, M. \& Bechet, I. 1960: Ciuperci parazite si saprofite pe insecte (1). - Studia Universitatis Babes-Bolyai. (Ser. 2) 2: 95-103.

Blackwell, M. 1980a: Incidence, host specificity, distribution and morphological variation in Arthrorhynchus nycteribiae and A. eucampsipodae (Laboulbeniomycetes). - Mycologia 72: 141-158.

- 1980b: Developmental morphology and taxonomic characters of Arthrorhynchus nycteribiae and A. eucampsipodae (Laboulbeniomycetes). - Mycologia 72: $159-168$.

Cavara, F. 1899: Di una nuova Laboulbeniacea: Rickia Wasmannii, nov.gen. e nov.spec. - Malpighia 13: 173188.

Cépède, C. \& Picard, F. 1908: Observations biologiques sur les Laboulbéniacées et diagnoses sommaires de quelques 
espèces nouvelles. - Comptes Rendus Assoc. Franç. Avancement Sci, $36^{\mathrm{e}}$ sess., Reims 1907: 778-784.

- 1909: Contribution à la biologie et à la systématique des Laboulbéniacées de la flore française. - Bull. Sci. Fr. Belg. 42: 247-268.

Colla, S. 1934: Laboulbeniales. - Flora Italica Cryptogamica 1 (Fungi 16): $1-157$

Collart, A. 1945: A propos des Laboulbéniacées. - Les Naturalistes Belges 26: 98-103.

Frank, J.H. 1982: The parasites of the Staphylinidae (Coleoptera). - Techn. Bull. Agric. Exp. St. Inst. Food Agric. Sci. Univ. Fla. 824: 1-118.

Hincks, W.D. 1960: Notes on the Laboulbeniales. - The Naturalist 1960: $97-102$.

Huldén, L. 1983: Laboulbeniales (Ascomycetes) of Finland and adjacent parts of the U.S.S.R. - Karstenia 21: 31 136.

Lepesme, P. 1942: Revision des Rhachomyces paléarctiques (Laboulbeniaceae). - Bull. Soc. Mycol. Fr. 58: 5780.

Maire, R. 1912: Contribution à l'etude des Laboulbéniales de l'Afrique du Nord. - Bull. Soc. d'Hist. Nat. Afr. Nord 4(9): 194-199.

- 1916: Deuxième contribution à l'étude des Laboulbéniales de l'Afrique du Nord. - Bull. Soc. d'Hist. Nat. Afr. Nord 7: 6-39.

- 1920: Troisième contribution à l'étude des Laboulbeniales de l'Afrique du Nord. - Bull. Soc. d'Hist. Nat. Afr. Nord 41: 123-138, 143-158, 159170.

Majewski, T. 1972: Rare and new Laboulbeniales from Poland 2. - Acta Mycol. 8: 229-237.

- 1973: Rare and new Laboulbeniales from Poland 3. Acta Mycol. 9: 111-124.

Middelhoek, A. 1949: Laboulbenaiaceae in Nederland 3. Nederl. Kruidk. Arch. 56: 249-260.

Peyritsch, J. 1871: Über einige Pilze aus der Familie der Laboulbenien. - Sitz. Ber. Kaiserl. Akad. Wiss. Math.Naturwiss. Klasse 64(1): $441-458$.

- 1873: Beiträge zur Kenntnis der Laboulbenien. - Sitz. Ber. Kaiserl. Akad. Wiss. Math.-Naturwiss. Klasse 68(1): $227-254$

Picard, F. 1913: Contribution à l'étude des Laboulbéniacées d'Europe et du nord de l'Afrique. - Bull. Soc. Mycol. France 29: $503-571$.

Robin, C. 1853: Histoire naturelle des végétaux parasites qui croissent sur l'homme et sur les animaux vivants. 704 pp. Paris.

Rossi, W. 1975: Su alcune Laboulbeniali (Ascomycetes) nuove per l'Italia. - Giorn. Bot. Ital. 109: 71-85.

- 1978: Sui Rhachomyces (Ascomycetes, Laboulbeniales) parassiti dei Duvalius italiani (Coleoptera, Carabidae, Trechini). - Int. J. Speleol. 10: 323-330.

Rossi, W. \& Cesari Rossi, G. 1979: Su alcune species di Stigmatomyces (Ascomycetes, Laboulbeniales) parassite di Ditteri italiani. - Boll. Mus. Civ. Venezia 30: 1318.

Ryberg, O. 1947: Studies on bats and bat parasites, especially with regard to Sweden and other neighbouring countries of the North. -330 pp. Stockholm.

Scheloske, H.-W. 1969: Beiträge zur Biologie, Ökologie und Systematik der Laboulbeniales (Ascomycetes) unter besonderer Berücksichtigung des Parasit-WirtVerhältnisses. - Parasitol. Schriftenr. 19: 1-176.

Siemaszko, J. \& Siemaszko, W. 1928: Owadorosty polskie i palearktyczne (Laboulbeniales polonici et palaearctici). - Polskie Pismo Entomol. 6: 188-211.

Spegazzini, C. 1912: Contribución al estudio de las Laboulbeniomicetas argentinas. - An. Mus. Nac. Hist. Nat. Buenos Aires 23: 167-244.

- 1914: Primo contributo alla conoscenza delle Laboulbeniali italiani. - Redia 10: 21-75.

- 1915a: Laboulbeniali ritrovati nelle collezioni di alcun musei italiani. - An. Mus. Nac. Hist. Nat. Buenos Aires 26: $451-511$.

- 1915b: Segunda contribución al conocimiento de las Laboulbeniales italianas. - An. Mus. Nac. Hist. Nat. Buenos Aires 27: 37-74.
- 1918: Observaciones microbiológicas. - An. Soc. Cient. Argent., Buenos Aires 85: 311-323.

Stadelmann, M. \& Poelt, J. 1962: Zur Kenntnis der mitteleuropäischen Laboulbeniales. - Ber. Bayer. Bot. Ges. 35: $120-132$.

Sugiyama, K. 1973: Species and genera of the Laboulbeniales (Ascomycetes) in Japan. - Ginkgoana 2: 1-97.

- 1978: The Laboulbeniomycetes of eastern Asia (2). On eight species from Japan and Formosa including two new species of Rickia. - J. Japan. Bot. 53: 154-160.

Thaxter, R. 1891: Supplementary note on North American Laboulbeniaceae. - Proc. Amer. Acad. Arts \& Sci. 25: $261-270$.

- 1892: Further additions to the North American species of Laboulbeniaceae. - Proc. Amer. Acad. Arts \& Sci. 27: $29-45$.

- 1893: New species of Laboulbeniaceae from various localities. - Proc. Amer. Acad. Arts \& Sci. 28: 156188.

- 1895: Notes on Laboulbeniaceae, with descriptions of new species. - Proc. Amer. Acad. Arts \& Sci. 30: 467481.

- 1896: Contribution towards a monograph of the Laboulbeniaceae. - Mem. Amer. Acad. Arts \& Sci. 12 187-429.

- 1899: Preliminary diagnoses of new species of Laboulbeniaceae 1. - Proc. Amer. Acad. Arts \& Sci. 35: $153-209$.

- 1900: Preliminary diagnoses of new species of Laboulbeniaceae 2. - Proc. Amer. Acad. Arts \& Sci. 35: $407-450$.

- 1901: Preliminary diagnoses of new species of Laboulbeniaceae 3. - Proc. Amer. Acad. Arts \& Sci. 36: $395-414$.

- 1905: Preliminary diagnoses of new species of Laboulbeniaceae 6. - Proc. Amer. Acad. Arts \& Sci. 41: $301-318$.

- 1908: Contribution towards a monograph of the Laboulbeniaceae 2. - Mem. Amer. Acad. Arts \& Sci. 13: $217-469$.

- 1931: Contribution towards a monograph of the Laboulbeniaceae 5. - Mem. Amer. Acad. Arts \& Sci. 16: $1-435$.

\section{Accepted for publication}

on September 15, 1984

\section{Errata}

In 'Laboulbeniales (Ascomycetes) of Finland and adjacent parts of the U.S.S.R.', Karstenia 21: 31-136, there were some disturbing errors and misprints, which should be corrected: page 48 left column line 49: for Figs. 30 read Figs. 40 page 55 left column line 26: for Agonum viduum (Panzer) read Agonum moestum Duftschmid. The same change should be made for Figs. $101 \mathrm{a}-\mathrm{d}$ page 109. This correction does not affect the statistics for A. viduum (pp. 123 and 131), but A. moestum should be added to the host-parasite list on p. 131 and to the parasite-host list on p. 135. page 56 right column line 24: for Fig. $88 \mathrm{~b}$ read $98 \mathrm{~b}$ page 59 left column line 62: for Fig. $81 \mathrm{~b}$ read $91 \mathrm{~b}$ page 59 right column line 1: for Fig. 81a read 9la

page 61 and elsewhere: for Monoicomyces oxytelis read Monoicomyces oxyteli

page 67 right column line 40: for Ylörjärvi read Ylöjärvi page 80 line 3: for italicus read halipli page 103 line 1: for b) immature read c)immature

page 121: Thaxter 1899-1912 are misplaced under Wize 1929

page 124 right column line 3: for fungus read fuscus page 130 line 24 (Elaphrus cupreus): add Laboulbenia elaphri page 132 line 65 (P. debilis): add (1) Dichomyces hybridus page 133 line 28: for elonngatus read elongatulus

page 135 column line 19: for Agonum septentrionis read Patrobus septentrionis

pages $46,111,124,132,135$ : Choleva septentrionis Jeannel should be interpreted as Choleva lederiana Reitter 